Trade Integration and Business Tax Differentials:

Theory and Evidence from OECD Countries

Nelly Exbrayat, Benny Geys

Août 2011 


\section{GATE Groupe d'Analyse et de Théorie Économique Lyon-St Étienne}

93, chemin des Mouilles 69130 Ecully - France

Tel. +33 (0)4 72866060

Fax $+33(0) 472866090$

6, rue Basse des Rives 42023 Saint-Etienne cedex 02 - France

Tel. +33 (0)4 77421960

Fax. $+33(0) 477421950$

Messagerie électronique / Email : gate@gate.cnrs.fr

Téléchargement / Download : http://www.gate.cnrs.fr - Publications / Working Papers 
Trade Integration and Business Tax Differentials:

Theory and Evidence from OECD Countries

Nelly Exbrayat, Benny Geys

Août 2011 


\section{GATE Groupe d'Analyse et de Théorie Économique Lyon-St Étienne}

93, chemin des Mouilles 69130 Ecully - France

Tel. +33 (0)4 72866060

Fax $+33(0) 472866090$

6, rue Basse des Rives 42023 Saint-Etienne cedex 02 - France

Tel. +33 (0)4 77421960

Fax. $+33(0) 477421950$

Messagerie électronique / Email : gate@gate.cnrs.fr

Téléchargement / Download : http://www.gate.cnrs.fr - Publications / Working Papers 


\title{
Trade Integration and Business Tax Differentials: Theory and Evidence from OECD Countries*
}

\author{
Nelly Exbrayat* and Benny Geys"
}

May 2011

\begin{abstract}
Building on recent contributions to the New Economic Geography literature, this paper analyses the relation between asymmetric market size, trade integration and business income tax differentials across countries. First, relying on a foot-loose capital model of tax competition, we illustrate that trade integration (or decreasing trade costs) reduces the importance of relative market size for differences in the extent of corporate taxation between countries. Then, using a dataset of 26 OECD countries over the period 1982-2004, we provide supportive evidence of these theoretical predictions: i.e., market size differences are strongly positively correlated with corporate income tax differences across countries but, crucially, trade integration weakens this link. These findings are obtained controlling for the potential endogeneity of trade integration and are robust to various alternative specifications and robustness checks.
\end{abstract}

Keywords: Tax competition, Trade integration, New Economic Geography, Tax differentials. JEL-Codes: H2, H3, C23, F12

\footnotetext{
* We are grateful to Simon Loretz for providing the tax data and to Fredrik Andersson, Kristian Behrens, Céline Carrère, Pierre-Philippe Combes, Vianney Dequiedt, Clemens Fuest, Christina Gathmann, Andreas Haufler, Tom Reiel Heggedal, Eckhard Janeba, Per Botolf Maureth, Espen Moen, Jordi Jofre-Monseny, Margarita Kalamova, Kai Konrad, Dirk Krueger, Simon Loretz, Gianmarco Ottaviano, Rodrigo Paillacar, Sonia Paty, Sandra Poncet, Grégoire Rota-Graziosi, Stéphane Riou, José De Sousa, Ian Wooton, Tanguy van Ypersele as well as participants of seminars at WZB, CERDI and IEB, Journées Gérard-Varet (Marseille, France), Journées Économie et Espace (Rennes, France), Tax Policy Decision-Making (Mannheim, Germany) and COMPNASTA (Lyon, France) workshops for helpful comments and suggestions. All remaining errors are ours.

* Université de Lyon, Lyon, F-69003, France ; Université Jean Monnet, Saint-Etienne, F-42000, France ; CNRS, GATE Lyon St Etienne, Saint-Etienne, F-42000, France. Email: Nelly.Exbrayat@univ-st-etienne.fr (Corresponding author).

- Norwegian School of Management BI, Nydalsveien 37, N-0442 Oslo, Norway. Email: Benny.Geys@ bi.no; and Social Science Research Center Berlin (WZB), Reichpietschufer 50, D-10785 Berlin, Germany. Email: geys@wzb.eu.
} 
"You've had a broad substantial reduction in corporate tax rates outside the US. That occurs at a time when it's much easier (...) for companies to shift investment and income to take advantage of lower tax rates overseas. (...) To have a more competitive system, you want to try to bring down the rate closer to the range of our major trading partners."

(Timothy Geithner, US Treasury Secretary, Wall Street Journal, 28-30 January 2011, 9)

\section{Introduction}

Looking at the evolution of corporate tax rates in developed countries over the last three decades, two central observations stand out. The first is a decline in corporate tax rates (Figure 1, lefthand side). For example, between 1982 and 2007 OECD countries on average reduced their statutory and effective average corporate income tax rates by, respectively, 41 percent (from an average of $47 \%$ to an average of $27 \%$ ) and 35 percent (from an average of $37 \%$ to an average of 24\%). ${ }^{1}$ While the highest statutory corporate tax rate within the OECD stood at $65 \%$ (Israel) in 1982, it had fallen to $41 \%$ (Japan) in 2007. The second is the presence of important corporate tax disparities across countries despite this downward trend in tax rates. Indeed, while the standard deviation of the distribution of effective marginal, effective average, and statutory tax rates across OECD countries fell substantially between 1982 and 2000, this decline appears to have bottomed out since then, even though significant variation remains (Figure 1, right-hand side).

\section{--- Figure 1 about here ---}

Recent empirical work indicates the important role of such tax differences for FDI flows or firm location (e.g., Bénassy-Quéré et al., 2005; Brülhart et al., 2009; Kammas, 2011). Empirical analyses aimed at understanding what allows some countries to sustain higher tax rates than others have, however, not followed suit. ${ }^{2}$ Yet, such insights can have important policy implications. The quote by US Treasury Secretary Geithner at the onset of this article, for example, indicates that a central reason behind the US' planned overhaul of the corporate

\footnotetext{
${ }^{1}$ This steep decline is also present when looking only at countries that were OECD members throughout the 19822007 period.

${ }^{2}$ While numerous studies analyse the decline in corporate tax rates (e.g., Devereux et al., 2002, 2008; Davies and Voget, 2008; Exbrayat, 2011), Gilbert et al. (2005) is, to the best of our knowledge, the only study analysing determinants of corporate tax rate differentials. Compared to that study, we provide a firmer theoretical rationale for the analysis, address potential endogeneity problems, control for the influence of various country-level variables, and employ a wider sample of countries (i.e., 26 OECD countries versus 15 European countries).
} 
taxation system lies in fears that increasing global economic integration is undermining the US' ability to sustain higher tax rates compared to its main trading partners. ${ }^{3}$

This article takes an initial step towards explaining what drives corporate tax differentials across countries, focusing on the role of economic integration. From a theoretical perspective, we exploit insights from the tax competition literature based on New Economic Geography (NEG) frameworks. Recent contributions to this literature indeed predict that, in an environment of increasing returns to scale and imperfect trade integration, the most populated countries can sustain higher corporate taxes because firms located in these countries enjoy an 'agglomeration rent' that reduces their sensitivity to countries' relative tax policies (Ludema and Wooton, 2000; Kind et al., 2000; Baldwin and Krugman, 2004). However, and crucially, bigger countries lose this advantage with increasing trade integration (or falling trade costs) because the site of production then becomes less relevant (Ottaviano and van Ypersele, 2005; Gaigné and Riou, 2007; Haufler and Wooton, 2010). Consequently, the NEG literature predicts that tax disparities across countries reflect the fact that some countries are exposed to tax competition to a different degree than others, depending on the level of trade costs and their relative market size. This paper's central contribution lies in assessing such claim's empirical relevance.

Our analysis proceeds in two stages. First, we exploit a simple foot-loose capital model of tax competition in spirit of Ottaviano and Van Ypersele (2005) and Haufler and Wooton (2010) to offer a detailed understanding regarding the role of asymmetric market size and trade integration for corporate tax differences across countries. This analytical treatment allows us to focus precisely on the two empirically testable predictions that follow from such models: $a$ ) tax differentials are a function of the coexistence of imperfect trade integration and asymmetric market sizes and $b$ ) increased trade integration reduces the ability of large countries to set higher taxes. Second, we evaluate these predictions employing data for 26 OECD countries (thus generating up to 325 country-pairs) over the period 1982-2004. Unlike existing empirical tax competition studies - which mostly estimate tax reaction functions, where the tax rate in one

\footnotetext{
3 Although we focus on international tax competition, countries often use a variety of measures to increase their attraction towards international firms. Pieretti and Zanaj (2011), for example, recently analysed the case where jurisdictions compete for foreign capital both via taxes and public inputs that enhance firms' productivity while Charlton (2003) looks at investment subsidies, which can often reach a substantial share of the investment's value. Also, some countries give preferential treatment to highly mobile tax bases (e.g., Ireland levies a lower tax rate on manufacturing and financial services compared to other sectors). We abstract from such cross-sectoral discrimination and refer the reader to, for example, Wilson (2005) and Marceau et al. (2010) for recent treatments.
} 
country is linked to a population- or distance-weighted average of competing countries' tax rates (e.g., Devereux et al., 2002, 2008; Davies and Voget, 2008; Exbrayat, 2011) - we thereby explicitly model the tax rate difference between each country-pair. The reason is threefold. First, the focus of reaction function analyses lies on absolute levels of taxation. This can be misleading, however, since what matters for firms' location choices - and thus also for tax competition - is the difference in corporate tax rates between countries rather than the absolute level of taxation in each country (see also Bénassy-Quéré et al., 2005). Moreover, tax differentials more directly capture the idea that investors arbitrate not only among foreign locations, but also between each foreign location and domestic investment. Finally, while estimation of tax reaction functions allows analysing the decline in corporate taxes rates, it does not provide direct insights regarding the determinants of tax differentials, which is our central concern.

Our results support the model's predictions. Specifically, we show that the tax gap responds positively to population size differences between countries and, crucially, that this relationship is significantly attenuated by trade integration. Our results provide strong evidence since the relatively highly-integrated nature of OECD countries' economies provides an environment least likely to expose substantial effects. Moreover, to properly identify the trade integration effect and control for the endogeneity of standard measures of trade integration, we extract the level of trade liberalisation between each country-pair from a gravity equation controlling for remoteness by the use of country fixed effects (Rose and Van Wincoop, 2001; Feenstra, 2003; Redding and Venables, 2004; Head and Mayer, 2011). Our findings are also robust to a number of alternative specifications (e.g., different definitions of the dependent variable) and robustness checks (e.g., accounting for third-country or income effects). As such, we provide significant empirical support for the idea, recently brought forward in the NEG literature, that tax disparities across countries reflect these countries' varying exposedness to international competitive forces.

The structure of the article is as follows. In the following section, we set up a foot-loose capital model of tax competition to derive testable hypotheses on the relation between corporate taxation, trade integration and population differences. The empirical verification of these predictions is described in section 3. The last section concludes and discusses some avenues for further research. 


\section{The model}

To derive testable predictions regarding the relation between asymmetric market size, trade integration and business tax differentials, we use the model of Ottaviano and Van Ypersele (2005) simplified, without loss of generality, by assuming oligopolistic rather than monopolistic competition. The economy consists of two imperfectly integrated countries $(i=1,2)$, which compete to attract firms. These firms produce a homogeneous good, labelled $x$, under increasing returns to scale and Cournot competition. Another private good, the numéraire $z$, is produced under perfect competition and is freely traded. There are two factors of production, physical capital and labour, whose total endowments are denoted $K$ and $L$, respectively. Total factor endowments are fixed and equally distributed across individuals in either country. However, we assume that a share $\sigma_{1}>0.5$ of the total population lives in country 1 . While these workers are immobile, they can invest their capital wherever they want. The public sector in each country is represented by a benevolent government, which imposes a lump-sum tax $t_{i}$ on capital invested in its country. If this tax is positive, the resulting tax revenues $T_{i}$ are redistributed in a lump-sum way to the workers, while if a government subsidizes capital these expenditures are financed through lump-sum taxation of workers. ${ }^{4}$

\subsection{Consumption}

Consumers in both countries share the same quasi-linear utility function:

$$
u_{i}=a x_{i}-\frac{\beta}{2} x_{i}^{2}+z_{i}
$$

with $a>0$ and $i \in\{1,2\}$. Every resident in the economy supplies one unit of labour. The wage rate in each country is determined in the numéraire industry, which uses labour as its only input and requires one unit of labour to produce one unit of the good. Free trade in the numéraire thus equalizes the wage across countries $(w)$ to unity. ${ }^{5}$ Moreover, each resident receives income from capital at the world net return to capital, denoted by $r$ (which is endogenously determined by a bidding process for capital, see below). Thus, the budget constraint for a representative consumer in country $i$ is:

\footnotetext{
${ }^{4}$ This framework is close to the standard model of asymmetric tax competition (Bucovetsky, 1991; Wilson, 1991), so that any differences in the model's predictions are only imputable to the assumption of imperfect competition and positive trade costs.

5 To ease the interpretation of our results, we denote the wage by $w$ (rather than 1 ) throughout the paper.
} 


$$
w+r \frac{K}{L}+\frac{T_{i}}{\sigma_{i} L}=z_{i}+p_{i} x_{i}
$$

where $p_{i}$ denotes the price of $\operatorname{good} x$ in country $i$.

Given (1) and (2), individual demand for the manufactured good in country $i$ is given by $x_{i}=\left(a-p_{i}\right) / \beta$ so that total demand for this good in each country is:

$$
X_{i}=\sigma_{i} L \frac{a-p_{i}}{\beta}
$$

Intuitively, aggregate demand is higher in the larger country as it benefits from a market size advantage (i.e., $\sigma_{1}>\sigma_{2}$ ), which makes its market more profitable for firms.

\subsection{Firms}

There are increasing returns to scale in the oligopolistic industry. Indeed, producing any amount of good $x$ requires a fixed amount of capital, which is normalized to one so that there is a perfect correspondence between the number of firms and the capital stock $(K)$. Besides, firms incur a marginal cost of one labour unit for each unit produced. ${ }^{6}$ This good is traded at a cost of $\tau$ units of the numéraire per unit shipped between the two countries, which raises the marginal cost of serving the foreign market to $(w+\tau)^{7}$

Firms are able to segment their markets by choosing the quantities to sell on the domestic and the foreign market independently. Therefore, operating profit of each firm in country $i$ is:

$$
\Pi_{i}=\left(p_{i}-w\right) x_{i i}+\left(p_{j}-w-\tau\right) x_{i j}
$$

where $x_{i j}$ denotes sales in country $j$. Maximizing profits taking into account demand (equation 3 ) yields the following output levels for a firm located in a country $i$ :

$$
x_{i i}=\frac{\sigma_{i} L}{\beta} \frac{a-w+\tau \lambda_{j} K}{K+1}, \quad x_{i j}=\frac{\sigma_{j} L}{\beta} \frac{a-w-\tau\left(\lambda_{j} K+1\right)}{K+1}
$$

where $\lambda_{j}$ stands for the share of firms in country $j\left(\right.$ with $\lambda_{i}+\lambda_{j}=1$ ). Intuitively, all else equal, an exporter sells less in any given market than an indigenous rival $\left(x_{i j}<x_{i i}\right)$ due to trade costs

\footnotetext{
${ }^{6}$ The marginal cost is normalised to zero in Ottaviano and Van Ypersele (2005). We normalise it to one so that the framework is closer to the standard tax competition literature where production of the private good requires capital and labour. The difference is, however, irrelevant for our results.

7 Trade costs must be understood in a general sense, as including non-tariff barriers and transportation costs.
} 
(although we focus here on the case where trade costs are low enough to ensure that $x_{i j}$ and $x_{j i}$ are positive). ${ }^{8}$ The resulting equilibrium price in country $i$ is:

$$
p_{i}=\frac{a+K \tau \lambda_{j}+w K}{K+1} .
$$

Three elements regarding this equilibrium price are worth noting explicitly. First, the consumer price level increases with trade barriers (because local firms are more protected against foreign competition). Second, it is decreasing in the number of firms located in this country (though this competition effect diminishes as trade costs fall). Finally, the export price net of transport cost (that is, $p_{i}-\tau$ ) is a decreasing function of trade costs and this relationship is strengthened by the toughness of competition in the foreign market.

Inserting these equilibrium prices in (4) yields an expression for short-run operating profits:

$$
\Pi_{i}^{*}=\frac{\sigma_{i} L}{\beta}\left(\frac{a-w+\tau \lambda_{j} K}{K+1}\right)^{2}+\frac{\sigma_{j} L}{\beta}\left(\frac{a-w-\tau\left(\lambda_{j} K+1\right)}{K+1}\right)^{2}
$$

In the long-run, net profits equal zero due to free entry and exit. ${ }^{9}$ Thus, the equilibrium rate of return is determined by a bidding process for capital, which ends when no firm can earn a strictly positive net profit at the equilibrium market price; that is,

$$
r_{i}=\Pi_{i}^{*}-t_{i} .
$$

The location equilibrium of capital can now be found by solving the arbitrage condition according to which no unit of capital can earn a higher net return by being invested in another country; that is, when $\Pi_{1}^{*}-t_{1}=\Pi_{2}^{*}-t_{2}=r$. The resulting share of firms in country 1 is:

$$
\lambda_{1}=\frac{1}{2}+\frac{2 \sigma_{1}-1}{2 K \tau}(2 a-2 w-\tau)-\frac{K+1}{2 K \tau^{2} L} \beta \Delta
$$

where $(2 a-2 w-\tau)$ is positive under the trade condition (see footnote 8) and $\Delta=t_{1}-t_{2}$ stands for the tax gap between countries 1 and 2. Let us first comment on the location of firms without taxation so that $\Delta=0$. As soon as trade is costly, the country with a larger demand for the increasing returns industry attracts more production relative to its population $\left(\lambda_{1}(\Delta=0)>\sigma_{1}\right)$

\footnotetext{
${ }^{8}$ Exports are profitable when $\tau<\tau_{\text {trade }}=(a-w) /(K+1)$, with $a>w$ so that it is also profitable to sell on the domestic market.

9 By contrast, Haufler and Wooton (2010) assume that there is no free entry so that firms retain positive profits also in the long run. While this assumption affects the equilibrium tax level, it is innocuous for the properties of the tax gap between countries (which is our prime concern).
} 
because firms save on trade costs by locating in this country. ${ }^{10}$ This is the 'home-market effect'. Importantly, there is a threshold of trade cost - i.e., $\tau_{C P}^{M}=2(a-w)\left(2 \sigma_{1}-1\right) /\left(K+2 \sigma_{1}-1\right)-$ under which it becomes so cheap to serve the foreign market through exports that a core-periphery structure emerges, characterized by the complete concentration of firms in the biggest country. Now, in the presence of different tax policies, the share of firms in country 1 will be relatively smaller (larger) than it would be at the free-market equilibrium (i.e., in the absence of governments and taxation) when that country sets the higher (lower) tax and $\Delta>0(\Delta<0)$. Importantly, firms' responsiveness to tax and population differentials are strengthened by the fall in trade costs, so that tax competition becomes fiercer.

\subsection{Tax competition}

We assume that each government is benevolent. Inserting the budget constraint in the national welfare, we get the following objective function for government of country $i$ :

$$
W_{i}=\sigma_{i} L S_{i}+T_{i}+\sigma_{i} L w+\sigma_{i} K r
$$

where $S_{i}=\left(a-p_{i}\right)^{2} / 2 \beta$ denotes consumer surplus. Thus, we can break down national welfare into four components: aggregate consumer surplus, tax revenues (redistributed to residents if $T_{i}>0$ or paid by them if $T_{i}<0$ ), total labour income and total return to capital. Before continuing the analysis, we briefly summarize how each component reacts to a change in taxation. By introducing equilibrium prices in the consumers' surplus, it is easy to show that each government has an incentive to set a low tax burden on capital $\left(d S_{i} / d t_{i}<0\right)$; this reduces the price prevailing in the domestic market, and increases domestic consumers' surplus. Yet, raising the capital tax has a positive effect on tax revenues $\left(T_{i}\right)$ provided that the tax base elasticity is less than one in absolute value. Both effects are stronger for the most populated country. Finally, the effect of taxation on the return to capital is a priori ambiguous. By inducing more competition among firms, a tax cut reduces operating profits, but the lower tax burden has a direct positive effect on the net return to capital. We can show that the latter effect dominates at the equilibrium, and that

\footnotetext{
${ }^{10}$ Even though the wage rate is equalised across countries, it erodes the attractiveness of country 1 . Intuitively, the negative impact of the wage rate on operating profits is proportional to the output, and is thus more detrimental to profits from domestic sales than those from foreign sales. Recalling that domestic sales are larger for firms located in the bigger market, the wage rate reduces the profit differential between country 1 and 2, and therefore reduces the relative attractiveness of country 1 .
} 
the negative effect of taxation on the return to capital is stronger in absolute terms for the smaller country.

We now solve the tax game by distinguishing between interior equilibria (when each country has some industrial firms) and the core-periphery equilibrium (when all industrial firms reside in the biggest country). The game takes place in two stages. In the first, governments simultaneously choose their tax rates while in the second, firms and consumers make their choices taking tax rates as given. The game is solved by backward induction.

\subsubsection{Nash tax gap under interior equilibrium configuration}

When trade liberalization is low enough for interior equilibria to be sustainable, the tax base elasticity in both countries is positive and the tax reaction functions are:

$$
\begin{aligned}
& t_{1}=\frac{2(K+1)-\sigma_{1}(2 K+1)}{4(K+1)-\sigma_{1}(2 K+1)} t_{2}+L \tau \frac{[2(a-w)-\tau]\left[K\left(3 \sigma_{1}-2\right)-\sigma_{1}\left(2 \sigma_{1}-5\right)+2\right]+2 K \tau\left(1-\sigma_{1}\right)(K+1)}{\beta(K+1)\left[2 K\left(2-\sigma_{1}\right)+4-\sigma_{1}\right]} \\
& t_{2}=\frac{2(K+1)-\left(1-\sigma_{1}\right)(2 K+1)}{4(K+1)-\left(1-\sigma_{1}\right)(2 K+1)} t_{1}+L \tau \frac{[2(a-w)-\tau]\left[1-\sigma_{1}\left(2 \sigma_{1}+1\right)-K\left(3 \sigma_{1}-1\right)\right]+2 K \tau \sigma_{1}(K+1)}{\beta(K+1)\left[2 K\left(2+\sigma_{1}\right)+3+\sigma_{1}\right]}
\end{aligned}
$$

These reaction functions have two important properties that contribute to explain why the government of the most populated country will set a higher tax rate. First, the slope is always positive so that taxes are strategic complements, and this slope is flatter for the most populated country. Second, the reaction functions' constant is higher for the most populated country. The resulting Nash tax gap between country 1 and 2 is:

$$
\Delta^{*}=\Omega \frac{\tau}{\beta} \frac{6(a-w)-\tau(2 K+3)}{4 K+5}
$$

where $\Omega=\left(2 \sigma_{1}-1\right) L$ stands for the difference in population between countries 1 and 2 and we verify that $\Delta^{*}$ is positive for non-prohibitive trade costs $\left(\tau \leq \tau_{\text {trade }}\right.$, see footnote 8$)$. From the second-order condition, it can be illustrated that this corresponds to a global optimum.

Equation (6a) first of all indicates that, for non-prohibitive trade costs, the tax gap between both countries is increasing with their population difference provided that trade costs are positive $\left(d \Delta^{*} / d \Omega>0\right.$ when $\left.\tau>0\right)$. Intuitively, because firms generate higher profits by locating in the largest market (by saving trade costs), the tax base elasticity is lower in this country, which allows its government to set a higher capital tax. The government of the less populated country on the other hand must compensate its firms for their location disadvantage 
via a lower capital tax. Secondly, however, equation (6a) shows that this relationship is mitigated as trade costs fall $\left(d^{2} \Delta^{*} / d \Omega d \tau>0\right) .{ }^{11}$ The reason is that trade integration reduces the positive impact of the difference in market sizes on the difference in operating profits. Since the bilateral tax gap is closely related with this difference in operating profit through the arbitrage condition, trade integration thus limits the ability of the largest country to set a higher tax than the small one. Finally, observe that the level of trade costs has no direct impact on the tax differential when countries are of equal size (i.e., when $\Omega=0$ ). It only matters through its influence on countries' relative market size (though trade integration clearly has a direct impact on absolute levels of taxation).

Substituting (6a) into (5), we get the share of firms located in the larger country in the presence of tax competition:

$$
\lambda_{1}^{*}=\frac{1}{2}+\frac{\Omega}{L} \frac{2(K+2)(a-w)+\tau\left(K+2 K^{2}-2\right)}{2 K \tau(4 K+5)}
$$

It is easy to verify that, despite the higher equilibrium tax rate of country 1 , it still hosts a more than proportional share of firms, and this home-market effect strengthens as trade costs fall. This explains why all capital is invested in the larger country as soon as trade costs fall under the threshold $\tau_{C P}^{*}=\left(2 \sigma_{1}-1\right)(K+2)(a-w) /\left[K\left(3-\sigma_{1}\right)+K^{2}\left(3-2 \sigma_{1}\right)+2 \sigma_{1}-1\right]$, with $\tau_{C P}^{*}<\tau_{C P}^{M}$.

\subsubsection{Tax gap under core-periphery equilibrium configuration}

Let us now consider the specific case where trade costs are so low $\left(\tau<\tau_{C P}^{*}\right)$ that all capital is invested in the largest country. Here, the world net return to capital is equal to the net return to capital in country 1 . Hence, the tax base elasticity in country 1 equals zero, while the welfare in country 2 is unaffected by a marginal rise in $t_{2}$. The government in 1 therefore sets its tax rate at the highest level compatible with the government in 2 being unable to affect the location of firms. ${ }^{12}$ Formally, this implies that the tax differential between both countries is equal to the difference in gross return to capital evaluated at $\lambda_{1}=1$. This yields:

\footnotetext{
11 This inequality holds for all $a>w$; that is, when domestic sales are profitable (see footnote 8 ).

12 The objective function of the government is strictly increasing in its tax rate. Indeed, when the tax base elasticity is equal to zero, raising the capital tax allows the government to increase tax revenues. The second-order condition is checked since $d_{1}^{2} W_{1} / d t_{1}^{2}=0$.
} 


$$
\Delta^{C P}=\tau \frac{(2 a-2 w-\tau) \Omega-K \tau}{\beta(K+1)}
$$

which is positive for all values of trade costs compatible with a core-periphery equilibrium (that is, $0<\tau \leq \tau_{C P}^{*}$ ) and zero in the absence of trade costs.

Clearly, the main property of the tax gap described in section 2.3 .1 still holds: i.e., the tax gap is increasing with the difference in population between both countries ( $d \Delta^{C P} / d \Omega>0$ when $\tau>0$ ), and this relationship is weakened as trade costs fall $\left(d^{2} \Delta^{C P} / d \Omega d \tau>0\right) .{ }^{13}$ Finally, observe that at the core-periphery equilibrium, trade costs exert a direct negative influence on the tax differential whereas they act only through the population differential at interior equilibria.

We summarize both results in the following proposition:

Proposition 1: Assume tax competition between two benevolent governments of differently populated countries. For positive but non-prohibitive values of trade cost $\left(\tau<\tau_{\text {trade }}\right)$ :

(i) the tax gap is increasing with the difference in population between both countries.

(ii) this relationship is mitigated as trade costs fall.

Before empirically testing these properties, we should note that they are robust to various extensions. First, as shown in Appendix A, Proposition 1 continues to hold in a three-country version of the model where country 1 not only competes with country 2 , but should also take its fiscal attractiveness relative to all other countries into account when deciding upon its tax policy (we retained the 2-country model in the main text as this is significantly more accessible). The existing literature on tax competition using NEG frameworks has, to the best of our knowledge, not addressed such three-country settings. Second, while not reported for reason of space, the above properties are robust to alternative assumptions regarding the government's behaviour: e.g., (1) the introduction of public good provision, (2) changes in the timing of events under the interior equilibria configuration (i.e., allowing the big country to act as Stackelberg leader in the tax game) and (3) allowing for Leviathan behaviour (full details available upon request). Finally, Ottaviano and Van Ypersele (2005) as well as Gaigné and Riou (2007) found qualitatively 
similar results as in Proposition 1 using a model where mobile firms produce horizontally differentiated goods and consumers have quasi-linear preferences with a love for variety.

\section{Empirical Analysis}

\subsection{Model specification}

To evaluate Proposition 1, we exploit an unbalanced panel of 26 OECD countries over the period 1982-2004 (thus having maximally 325 country-pairs per period). ${ }^{14}$ Our baseline regression is:

$$
\operatorname{TaxGap}_{i j t}=\beta_{1} \varphi_{i j t}+\beta_{2} \operatorname{PopGap}_{i j t}+\beta_{3}\left(\operatorname{PopGap}_{i j t} \times \varphi_{i j t}\right)+\beta_{4} Y_{i j t}+O_{i}+D_{j}+\eta_{t}+\varepsilon_{i j t}
$$

where $i j$ refers to a country-pair with $i \neq j$ and $t$ indexes time. Before discussing the operationalisation of the constituent parts of this model, two comments are required. First, one could argue that a natural alternative to this linear specification would start by taking the logarithm of equation $6 \mathrm{a}$, and estimate a loglinear specification. Clearly, however, given the large number of negative values that arises from the construction of both dependent and independent variables (i.e., as the difference between the values of countries $i$ and $j$; see below for details), such loglinear specification is empirically unfeasible. ${ }^{15}$ Second, although this specification is general enough to test the main results of the model extended to the case of three countries (Proposition 1-bis in Appendix A), the explicit two-country set-up in the baseline model above may be deemed problematic in a multi-country world. Still, as will be discussed in more detail below, we address the potential influence of 'third countries' in a number of ways throughout the analysis (see the end of this section, as well as section 3.4.3). This not only mitigates concerns about possible mis-specification bias, it also evaluates the robustness of our results to the exact operationalisation of such third-country effects.

The dependent variable - i.e., the tax gap between a pair of countries $\left(\operatorname{TaxGap}_{\mathrm{ijt}}\right)$ - is defined as the difference between the Effective Average Tax Rate (EATR) on firms in countries $i$ and $j$ at time $t$. We thereby employ a weighted average of the EATR levied on machinery and buildings

\footnotetext{
${ }^{13}$ In the extreme case of a perfectly integrated economy (that is, $\tau=0$ ), firms are indifferent between locating in 1 or 2 , so that both governments set equal tax rates.

${ }^{14}$ The set of countries includes Australia, Austria, Canada, Switzerland, Germany, Denmark, Spain, Finland, France, Great-Britain, Greece, Hungary, Ireland, Italy, Iceland, Japan, Korea, Mexico, the Netherlands, Norway, New-Zealand, Poland, Portugal, Sweden, Turkey and US. The starting point follows from the availability of corporate tax rate data (source: Loretz, 2008), while the endpoint is due to the lack of trade data after 2004 (source: CEPII).

${ }^{15}$ Redressing this negative-numbers problem by taking absolute values is also inappropriate as it critically changes the distribution of our main variables.
} 
(see Loretz, 2008, for details of the weighting scheme), although using the EATR on buildings or machinery does not affect our main findings (details upon request). Clearly, as the tax gap between countries $i$ and $j$ is the same as that between countries $j$ and $i$, we only include each country-pair once per year (and select those country-pairs $i j$ where country $i$ was alphabetically prior to country $j$ ). Note also that we employ EATR rather than the Effective Marginal Tax Rate (EMTR) or the statutory tax rate for two reasons. First, the statutory tax rate does not include tax base effects and firms are likely to decide their investment decisions based on what the entire tax schedule (i.e., tax base and tax rate) implies for them. Second, as our theoretical analysis is inspired by competition over 'greenfield', rather than additional, investments, ${ }^{16}$ EATR is the relevant measure for firms' decision-making. Nevertheless, for reasons of comparison and robustness, we run our estimations also with EMTR and the statutory tax rate (see below).

There are two central explanatory variables. First, PopGap ${ }_{\mathrm{ijt}}$ stands for the difference in population size between countries $i$ and $j$ at time $t$ (in million people) and analyzes how the tax gap responds to population size differences between countries (part $i$ ) of Proposition 1). One could argue that this reliance on the population difference takes the theoretical model overly literal, and that a measure based on the difference in GDP or market potential would be more appropriate (since $\Omega$ effectively measures the relative size of the market). We refrain from using the difference in GDP to test the model because this creates an obvious endogeneity problem. This is not the case for the population-based measure since we are analysing corporate taxation, which arguably leaves individuals' residence decisions - and thus the relative size of the countries' populations - unaffected. Moreover, the population difference provides a credible measure of the relative market size since it is strongly and significantly positively related to the GDP-difference $(r=0.21 ; \mathrm{p}<0.01)$ as well as the market potential difference $(r=0.65 ; \mathrm{p}<0.01$; this variable is defined in more detail in section 3.2 below). Nonetheless, we also report results using the latter, more general measure of market potential since multinationals set up in any given country - but especially for centrally located ones - may serve neighbouring countries as well (for these robustness checks, see section 3.4.4). ${ }^{17}$

Second, to address part ii) of Proposition 1, we introduce the level of trade liberalisation $\left(\varphi_{\mathrm{ijt}}\right)$ - which approximates the effect of trade costs deriving from various impediments to trade

16 What is taxed is the return to capital employed as a fixed cost in the modern industry, which is equal to firms' operating profits. 
and corresponds to the general interpretation of trade costs in the theoretical model (see note 7) and interact it with PopGap $\mathrm{ijt}_{\mathrm{j}}$. Given the endogeneity of traditional trade openness measures (i.e., imports and exports as a share of GDP), our identification strategy here rests on estimating $\varphi_{\mathrm{ijt}}$ from a gravity equation controlling for remoteness by the use of country fixed effects (Rose and Van Wincoop, 2001; Feenstra, 2003; Redding and Venables, 2004; for details, see section 3.3 below). Larger values of $\varphi_{\mathrm{ijt}}$ indicate closer trade integration (and thus lower trade costs), implying that Proposition 1 predicts a positive sign for $\beta_{2}$ and a negative one for $\beta_{3}$.

We also include $\varphi_{\mathrm{ijt}}$ independently in the empirical model. This is not only needed to avoid biased inferences on its interaction with the population differential, but also allows testing whether trade integration fails to have a direct impact on the tax differential - as predicted by equation $6 a^{18}$ Specifically, equation (6a) indicates that the level of trade costs only matters through its influence on countries' relative market size at interior equilibria, whereas it has a direct and negative influence on the tax gap at the core-periphery equilibrium. Consequently, a statistically insignificant coefficient $\beta_{1}$ would suggest that all governments consider the tax base elasticity to be positive, whereas a significant $\beta_{1}$ rather indicates that one government in each country-pair behaves as if all industrial firms were located in its country and tax base elasticity equals zero.

The vector $Y$ represents a number of control variables that can be expected to affect tax rates in both countries, and therefore the tax gap between these countries. Specifically, building on a large political economics literature, we include the difference in country-pairs' real GDP (in ten million dollars), public consumption (i.e., public sector size as a share of GDP), urbanness (share of population in urban areas), share of young and old in the population (under 14 and over 65 respectively), unemployment rate, openness (imports plus exports as a share of GDP), political leaning of the government ( 1 if right-wing, 0 if centre and -1 if left-wing), a simple linear time trend and two dummy variables equal to 1 when one or both countries are part of the European Union or its precursors. ${ }^{19}$ Data definitions, summary statistics and sources are in appendix B.

\footnotetext{
${ }^{17}$ Note that potential endogeneity of countries' overall market potential is negligible compared to that of their GDP.

18 Still, excluding $\varphi_{\mathrm{ijt}}$ from the model does not affect our findings in any way.

19 The trade openness variable is used to control for the impact of multilateral - rather than bilateral - trade integration on tax differentials. As such, we evaluate the effect of bilateral trade integration, given the extent of multilateral trade integration. Our results remain unchanged, however, when excluding this variable.
} 
Finally, $O_{i}$ and $D_{j}$ represent a vector of country of 'origin' (i.e., first in our country-pair) and 'destination' (i.e., second in our country-pair) indicator variables and $\eta_{\mathrm{t}}$ is a set of year dummies, which pick up country-specific and time-specific effects. Importantly, inclusion of these fixed effects goes some way towards mitigating the potential bias of not explicitly introducing thirdcountry effects in the empirical model (as mentioned, however, we return to such effects in section 3.4.3). ${ }^{20}$ Note that we also experimented with country-pair fixed effects. As this alternative specification does not affect our main findings (details upon request), but more strongly reduces our degrees of freedom, we retain separate origin and destination fixed effects in the main analysis.

\subsection{Measuring trade liberalization (and market potential)}

Following Head and Mayer (2011), we estimate bilateral trade relations from a gravity equation which takes the following simple multiplicative form: ${ }^{21}$

$$
X_{i j}=F X_{i} \times \varphi_{i j} \times F M_{j}
$$

with $X_{i j}$ the exports from country $i$ to country $j, \varphi_{i j}$ the freeness of trade, and $F X_{i}$ and $F M_{j}$ as exporter and importer fixed effects. Formally, $\varphi_{i j}=\tau_{i j}^{1-\sigma}$, with $\tau_{i j}$ the bilateral iceberg costs and $\sigma$ the elasticity of substitution between varieties. The exporter fixed effects typically capture the export capabilities of country $i$ while the importer fixed effects capture demand from country $j$. As standard in the literature, we consider that trade freeness depends on several variables that either enhance or deter trade: bilateral distance $\left(\right.$ Dist $\left._{i j}\right)$, a dummy for contiguity $\left(C_{i j}\right)$, a dummy for common language $\left(L_{i j}\right)$ and a dummy for colonial links $\left(C_{0} l_{i j}\right)$. Such historical elements provide a critical source of exogenous variation. Taking logs, our gravity regression is specified as follows:

$$
\ln X_{i j t}=F X_{i t}+F M_{j t}+\delta \ln D_{i s t_{i j}}+\lambda_{1} C_{i j}+\lambda_{2} L_{i j}+\lambda_{3} C_{o l}+u_{i j t}
$$

Attempts to include time-varying trade policy variables - such as membership of regional trade agreements - proved unsuccessful (i.e., the estimation model often fails to converge) as

\footnotetext{
${ }^{20}$ We thank José De Sousa for fruitful comments and discussions on this point.

${ }^{21}$ We choose this empirical model because a wide range of different micro-foundations yield such an equation. Those include Dixit-Stiglitz' (1977) model of monopolistic competition, Anderson and van Wincoop's (2003) model based on national product differentiation, comparative advantage models such as Eaton and Kortum (2002) and, more recently, models incorporating firm heterogeneity with monopolistic competition and endogenous mark-ups using a linear demand system as in our framework (see Melitz and Ottaviano, 2008).
} 
there is not enough heterogeneity in our sample with respect to these variables. ${ }^{22}$ To nonetheless account for such temporal influences, we estimate the trade cost equation separately for every year. This not only allows trade costs to change for each country-pair in each year, it also does so without imposing a predefined functional form on such changes - unlike, for instance, when introducing dummy variables for regional trade agreements or the fall of the Berlin Wall. This flexibility is important to pick up trade cost changes when they de facto occur (not when we would de jure expect them), and allows the strength of such effects to develop over time (rather than imposing a constant effect). The resulting model - estimated using bilateral trade data over the period 1980-2004 with data for trade liberalisation (both provided by the CEPII) - provides a very good approximation of trade flows, with an average $\mathrm{R}^{2}$ of $98 \%$ (88\% when looking exclusively at variation within country-pairs over time), and variables used as trade cost proxies are statistically significant well beyond the $99 \%$ confidence level. From this set of estimations, we extract predicted values for bilateral trade integration as follows (see also Head and Mayer, $2011):^{23}$

$$
\hat{\varphi}_{i j t}=\operatorname{Dist}_{i j}^{\hat{\delta}} \exp \left(\hat{\lambda}_{1} C_{i j}+\hat{\lambda}_{2} L_{i j}+\hat{\lambda}_{3} \operatorname{Col}_{i j}\right)
$$

Summary statistics for this measure are provided in Appendix B. These illustrate that the over-time (i.e., within country-pairs) standard deviation is larger than its cross-section (i.e., between country-pairs) standard deviation. Hence, the estimated trade integration measure varies substantially both in space and time. Moreover, it picks up important shifts in trade integration among OECD countries: e.g., our measure records substantial increases immediately following the fall of the Berlin Wall in 1989, in the period surrounding the Austrian-Finnish-Swedish EUaccession in January 1995 and around the large-scale eastward EU enlargement in May 2004, as well as a marked decline during the 1997-1998 global financial crises.

While this estimation of $\varphi_{\mathrm{ijt}}$ has a clear theoretical underpinning and addresses the endogeneity issue, extracting it from such first-stage regressions makes it a 'generated regressor'. Fortunately, OLS leads to consistent coefficient estimates in the presence of generated regressors

\footnotetext{
${ }^{22}$ Moreover, regional trade agreements may be endogeneous (Baier and Bergstrand, 2007).

23 One can similarly extract a measure for a country's overall market potential: i.e., $\hat{R m p_{i t}}=\sum_{j} \exp \left(\hat{F M_{j t}}\right) \hat{\varphi}_{i j t}$ (see Head and Mayer, 2011). We use this measure in the robustness check in section 3.4.4 below).
} 
(Pagan, 1984). Moreover, and crucial, while the estimated covariance matrix of the tax gap estimation needs to be adjusted to account for the variability in the trade integration variable when evaluating specific hypothesis tests, it still allows correct inference on whether the coefficient estimate of the generated regressor significantly differs from 0 . Hence, it allows consistent significance tests, which is our prime interest here (for details, see Pagan, 1984; for a similar approach, see Head and Mayer, 2006).

\subsection{Empirical results}

Our key results are summarized in Table 1. Column (1) presents baseline results when using the OLS estimator. In Column (2), we relax the implicit assumption that both countries' population sizes have the same effect on the tax differential between them, as this may conceal potential asymmetries in the observed effects. Hence, Column (2) presents results where we include the population size of the 'origin' and 'destination' country separately - each interacted with the bilateral measure for trade integration. As all country-pairs $i j$ have country $i$ alphabetically prior to country $j$ (see above), 'origin' and 'destination' here simply imply that a country is comes first in the alphabet. Although the relative strength of the population variables therefore cannot directly be interpreted (as this obviously depends upon which country is selected as 'origin' or 'destination'), it does allow evaluating whether any asymmetries exist in the country size effect. ${ }^{24}$ Throughout the analysis, we rely on Newey-West heteroscedasticityconsistent standard errors and cluster standard errors by country-years to account for the nonindependence of observations (i.e., the fact that a change in the corporate tax rate in country $i$ in year $t$ not only affects country-pair $i j$, but also all other country-pairs including $i$ ). Such clustering is feasible as we have a large number of clusters (450) with relatively few observations (25 or less) in each cluster (see Wooldridge, 2003). ${ }^{25}$

\section{--- Table 1 about here ---}

\footnotetext{
${ }^{24}$ We are grateful to Simon Loretz for pointing this possibility out to us.

${ }^{25}$ Note that each country-pair is simultaneously part of two clusters (i.e., one for the origin-country in year $t$ and one for the destination-country in year $t$ ). As these two sets of clusters are by construction highly correlated and partially overlapping, clustering standard errors simultaneously in both dimensions is impossible. To alleviate this problem, we ran all regressions using either origin-year or destination-year clustering and report the most conservative estimates obtained (i.e., origin-year clustering).
} 
We find that the difference in population size has a positive and highly statistically significant impact on the difference in effective average tax rates between countries when trade integration is absent (i.e., $\varphi_{i j t}=0$ ). Hence, in line with predictions from standard asymmetric tax competition models without trade (e.g., Wilson, 1991; Bucovetsky, 1991), a bigger country can and does - set a higher corporate income tax rate.

Including the impact of trade integration on the relation between population differences and the tax gap, we see in Column (1) that, as expected, increasing trade integration significantly reduces the impact of the population differential on the tax gap. The exact relation is depicted in Figure 2 (left-hand side). Even though the population differential retains a statistically significant effect at conventional levels throughout the entire range taken by the trade integration variable (i.e., the $90 \%$ confidence intervals - calculated to account for the covariance of the two variables - do not cross zero within this interval), the strength of this effect is decreasing in trade integration. This finding confirms part ii) of Proposition 1, and illustrates the empirical relevance of the models of tax competition based on New Economic Geography frameworks. It suggests that tax disparities across countries can indeed be partly explained by the fact that some countries are exposed to tax competition to a different degree than others.

\section{--- Figure 2 about here ---}

Interestingly, Column (1) also indicates that trade liberalization has no direct impact on the tax gap when both countries are of equal size (i.e., when $\Omega=0$ ), which is in line with theoretical predictions for interior equilibria (see equation 6a). However, using the interaction term to calculate the effect of trade integration over the entire range of population differential in our sample, we find that it does significantly affect the tax differential whenever the population differential exceeds roughly 100 million inhabitants (which is the case in about $15 \%$ of our sample). The exact relation is depicted in Figure 2 (right-hand side). When the population differential is 'large enough', the effect of trade integration is to decrease the tax rate of the larger country relative to that of the smaller one. This provides support for the theoretical prediction that, for interior equilibria, the overall effect of trade integration on the bilateral tax differential is negative (from the perspective of the bigger country). 
In column (2), we find that the tax gap is significantly positively affected by the size of the 'origin' country and significantly negatively by that of the 'destination' country. This is in line with expectations. Moreover, the difference in coefficient estimates for origin- and destinationcountries indeed suggests an asymmetry across countries. Coefficient estimates for the origin countries are higher (in absolute values), and the mediating effect of trade integration through the population of destination countries is somewhat weaker (in a statistical sense). Nonetheless, in both cases, the results confirm the predictions from the theoretical model: i.e., trade integration weakens the link between market size differences and corporate income tax differences across countries. $^{26}$

Turning briefly to our control variables, we find that the sign of the unemployment difference is at odds with the idea that higher unemployment is costly in terms of unemployment benefits (leading to higher tax rates). Rather, it suggests that governments use corporate tax cuts as a device to reduce unemployment by attracting new firms (e.g., Exbrayat et al., 2010; Haufler and Mittermaier, 2011). The difference in the share of youngsters across countries is associated with a significantly reduced corporate tax gap between these countries, while the difference in share of elderly has no consistent effect across estimations. The GDP-gap, differences in urbanness and governments' political leaning have no consistent effect (in terms of either sign and/or statistical significance) across different specifications. EU membership of one of both countries never has an independent additional effect on the corporate tax gap between them (for related findings, see Besley et al., 2001; Crabbé and Vandenbussche, 2008; Davies and Voget, 2008).

\subsection{Robustness analyses}

\subsubsection{Persistence and alternative corporate tax measures}

Since the tax gap between countries - just like the tax rates of individual countries - is likely to show significant persistence over time, it appears reasonable to evaluate whether any such persistence affects our core findings (even though no clear argument in favour of such inclusion

\footnotetext{
26 Note that the $\varphi$-coefficient is statistically significant in Column (2). This should, however, not be mis-interpreted as it derives from the difference in the empirical specification. Indeed, in Column (1), the $\varphi$-coefficient gives the effect of trade liberalization when countries are equal-sized whereas in Column (2) it describes the effect of trade liberalization when the population is equal to zero in both the origin and destination countries (a much more stringent condition, which, obviously, does not occur in our data).
} 
flows from our theoretical model). Hence, we re-estimated the model including a lagged dependent variable. Although panel-data estimators are well-known to generate biased and inconsistent results in the presence of a lagged dependent variable, the length of our time series (over 20 years) implies that any such bias is likely to be small (Nickell, 1981). Nonetheless, we cautiously instrument the lagged dependent variable with two further lags. ${ }^{27}$ The results are given in Columns (3) and (4) of Table 2, and indicate the there is substantial persistence in tax differentials, but, crucially, this does not affect our core findings. Trade integration consistently mitigates the link between market size differences and corporate income tax differences. ${ }^{28}$

In the remaining columns of Table (2), we furthermore illustrate that this same conclusion holds for alternative operationalisations of the tax measure. Although the theoretical model is predicated on greenfield investments (see above), Columns (5) through (10) evaluate the empirical model's robustness by using statutory tax rates and Effective Marginal Tax Rates (EMTR). A priori, one would expect weaker effects when using EMTR-differences between country-pairs as the dependent variable. The reason is that this measure of taxation is relevant for marginal investment decisions rather than discrete ones. For differences in statutory tax rates between countries (Stattax), however, one could expect similar if not stronger results than those for EATR. Statutory tax rates are the most directly observable measure of corporate taxation, and can thus more easily be compared from one country to another.

\section{--- Table 2 about here ---}

The results in Table 2 confirm the above intuitions. While the results are qualitatively similar to those in Table 1, the model performs better when using EATR rather than EMTR as dependent variable. Indeed, both the static and dynamic model's $\mathrm{R}^{2}$ reaches its lowest level when we use EMTR (see Columns (5) through (7)). Using statutory tax rate differences (i.e., Columns

\footnotetext{
${ }^{27}$ A similar approach to instrumenting the lagged dependent variable is taken in Devereux et al. (2008). The validity of these instruments is confirmed by a standard Hansen test in all regressions (except when using the statutory tax as dependent variable, see Table 2).

${ }^{28}$ Alternatively, we could account for persistence by calculating autocorrelation-robust standard errors. Specifying the model with a kernel-based estimation of standard errors that are robust to both arbitrary heteroskedasticity and arbitrary autocorrelation (using the Bartlett or Newey-West kernel and specifying bandwidths ranging between two and five) leaves all results qualitatively unaffected (details upon request).
} 
(8) through (10)), we find largely similar results than those when using EATR in section 3.3 above (except that the dynamic regression does not pass the Hansen test).

Note also, as indicated above, that our results are robust to using the tax rate levied on investments in machinery, buildings or a weighted average of both. This holds for EATR as well as EMTR (details upon request).

\subsubsection{Non-linear trade cost effects?}

As a corollary to the analysis of the Nash tax gap (see section 2.3), it is interesting to point out that trade costs have a non-linear effect on the tax gap between countries as soon as there is a positive population gap. Specifically, tax disparities can be shown to exhibit a concave relation with trade costs $\left(d^{2} \Delta^{*} / d \tau^{2}<0\right)$. This holds both for the interior equilibrium (in section 2.3.1) and the core-periphery equilibrium (in section 2.3.2) - with the sole difference that the relationship between the tax gap and trade costs is not strictly increasing (but rather humpshaped with a maximum value at $\tau=\tau_{C P}^{M} / 2$ ) in the latter case (Figure 3).

\section{--- Figure 3 about here ---}

To illustrate this more formally, note that equations (6a) and (6b) can also be rewritten as, respectively:

$$
\begin{aligned}
& \Delta^{*}=\frac{6(a-w)}{\beta(4 K+5)} \Omega \tau-\frac{(2 K+3)}{\beta(4 K+5)} \Omega \tau^{2} \\
& \Delta^{C P}=\frac{2(a-w)}{\beta(K+1)} \Omega \tau-\frac{L K+\Omega}{\beta(K+1)} \tau^{2}
\end{aligned}
$$

This corollary can be evaluated by estimating a slightly extended version of our empirical model:

$$
\begin{aligned}
\operatorname{TaxGap}_{i j t}= & \delta_{1} \varphi_{i j t}+\delta_{2} \varphi_{i j t}^{2}+\delta_{3} \text { PopGap }_{i j t}+\delta_{4}\left(\operatorname{PopGap}_{i j t} \times \varphi_{i j t}\right) \\
& +\delta_{5}\left(\operatorname{PopGap}_{i j t} \times \varphi_{i j t}^{2}\right)+\delta_{6} Y_{i j t}+O_{i}+D_{j}+\eta_{t}+\varepsilon_{i j t}
\end{aligned}
$$

The results are given in Table 3. Clearly, given the presence of the interaction terms between trade integration and the population differential, the results on $\varphi$ and $\varphi^{2}$ cannot be directly interpreted as marginal effects. Nonetheless, it can be easily observed that in both the static and dynamic model our results reject the prediction that tax disparities are a concave function of 
trade costs. Specifically, to the limited extent that such non-linearity exists in the data, it points in the opposite direction (note that this finding persists when dropping the interaction terms; available upon request). One potential explanation is that the large majority of our sample concerns highly developed countries with relatively high levels of trade integration. Consequently, variation in integration in our sample might well be too limited to pick up these finer distinctions. Unfortunately, however, data from a wider sample of countries is unavailable.

\section{--- Table 3 about here ---}

\subsubsection{Third country effects with asymmetric trade costs}

The three-country extension of our theoretical model described in appendix A (where the third country is interpreted as the rest of the world) illustrates that, when all country-pairs share the same level of trade integration, proposition 1 still holds regarding the most realistic case of interior equilibria. While the analytical expressions become quite complex in a theoretical model allowing for variation in trade integration across country-pairs, it seems reasonable to lift this restriction in the empirical analysis. This, however, is not innocuous with respect to the empirical specification. Clearly, symmetric levels of trade integration between three countries (denoted 1, 2 and 3) imply that country 1 and 2 enjoy the same access to country 3 . This makes that the relative attractiveness of country 1 with respect to country 2 - which drives their difference in tax base elasticity and the tax gap between them (see above) - is unaffected by both countries' relation to country 3 . As serving the market in country 3 is just as easy from country 1 than 2 , this plays no role in the tax-setting process. Allowing for asymmetric trade integration, this is no longer true and the attractiveness of country 1 relative to country 2 will now also depend on both countries' relative size and integration with country 3 . The reason is that this reflects how profitable it is to serve the third country from country 1 as compared to country 2 . Consequently, the bilateral tax gap (i.e., between country 1 and 2) will then also depend on the population differentials and bilateral levels of trade integration with respect to the third country. This implies extending the empirical model in the following way when accounting for third country effects with asymmetric trade costs:

$$
\begin{aligned}
& \text { TaxGap }_{i j t}=\beta_{1} \varphi_{i j t}+\beta_{2} \varphi_{i k t}+\beta_{3} \varphi_{j k t}+\beta_{4} \text { PopGap }_{i j t}+\beta_{5} \text { PopGap }_{i k t}+\beta_{6} \text { PopGap }_{j k t} \\
& +\beta_{7}\left(\text { PopGap }_{i j t} \times \varphi_{i j t}\right)+\beta_{8}\left(\text { PopGap }_{i k t} \times \varphi_{i k t}\right)+\beta_{9}\left(\text { PopGap }_{j k t} \times \varphi_{j k t}\right)+\beta_{10} Y_{i j t}+O_{i}+D_{j}+\eta_{t}+\varepsilon_{i j t}
\end{aligned}
$$


where we expect positive signs for $\beta_{5}$ and $\beta_{9}$, negative ones for $\beta_{6}$ and $\beta_{8}$ and signs as before for $\beta_{4}$ and $\beta_{7}$. The intuition is the following: i) PopGap ${ }_{i k t}$ exerts a positive influence on the absolute level of taxation in country $i$ (and, ceteris paribus, also on TaxGap $p_{i j t}$ ) while PopGap pkt $_{\text {exerts a }}$ positive influence on the absolute level of taxation in country $j$ (and, ceteris paribus, a negative influence on $\operatorname{Tax}_{a}{ }_{i j t}$ ) and ii) both relationships are attenuated by trade integration.

Unfortunately, we cannot estimate this regression directly because of a severe collinearity problem. Indeed, when the difference in population between countries $i$ and $j$ increases, it mechanically increases (decreases) the population gap between country $i(j)$ and the rest of the world. To overcome this problem, we redefine the third-country part of the model in terms of the population of country $i$ relative to the total population in the 26 OECD countries in our sample. The resulting variable - RelPop ${ }_{i k t}$ - is independent of PopGap $i j$, and the difference in population between country $j$ and $k$ is (weakly) negatively correlated with PopGap ${ }_{i j t}$ so that a change in

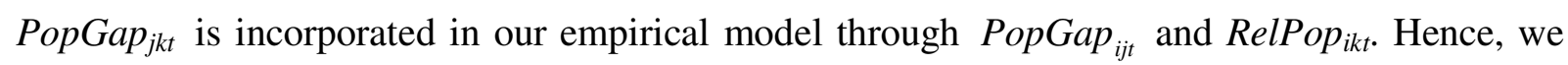
estimate the following regression, where $O_{p e n} n_{i k t}$ denotes the overall trade openness of country $i$ :

$$
\begin{aligned}
\operatorname{TaxGap}_{i j t} & =\beta_{1} \varphi_{i j t}+\beta_{2} \text { PopGap }_{i j t}+\beta_{3}\left(\text { PopGap }_{i j t} \times \varphi_{i j t}\right)+\beta_{4} \text { Open }_{i k t}+\beta_{5} \text { RelPop }_{i k t} \\
& +\beta_{6}\left(\text { RelPop }_{i k t} \times \text { Open }_{i k t}\right)+\beta_{7} Y_{i j t}+O_{i}+D_{j}+\eta_{t}+\varepsilon_{i j t}
\end{aligned}
$$

Results are reported in Table 4. First, we can observe that controlling for third country effects does not affect our main results: that is, the tax differential between $i$ and $j$ remains increasing with their population gap and this relationship is weakened by bilateral trade integration. The coefficient estimates are also very similar, suggesting that subsuming third-country effects into our fixed effects did not generate significant bias in our inferences. Second, the results provide evidence for the existence of significant third-country effects. As expected, the relative size of a country with respect to the rest of the world has a positive impact on its tax difference with country $j$, and this relationship is significantly weakened by its trade openness to the world.

\section{--- Table 4 about here ---}

\subsubsection{Income effects}

One central simplification of the theoretical model is that it abstracts from income effects by approximating demand in country $i$ by its population size and assuming quasi-linear preferences. 
To overcome this, we can introduce a more general measure for countries' market potential. Specifically, we rely on the real market potential variable provided by the CEPII, which has several advantages. ${ }^{29}$ First, it is estimated from a theory-grounded gravity equation, which implies that trade liberalisation is estimated rather than approximated by, say, the inverse of distance (see section 3.3). Second, it takes into account that the market potential of a country is not only increasing with demand coming from other countries but also decreasing with the average price in those countries. Finally, it is estimated using a dataset covering more than 150 countries, thus allowing us to indirectly take into account third-country effects.

Using this real market potential variable, we estimate the following regression:

$$
\operatorname{TaxGap}_{i j t}=\beta_{1} \varphi_{i j t}+\beta_{2} \operatorname{RmpGap}_{i j t}+\beta_{3} Y_{i j t}+O_{i}+D_{j}+\eta_{t}+\varepsilon_{i j t}
$$

where RmpGap ${ }_{i j t}$ denotes the difference in the real market potential of countries $i$ and $j .{ }^{30} \mathrm{We}$ expect $\beta_{2}$ to be positive, since, all else equal, an increase in the real market potential in country $i$ means this country becomes more profitable for firms and thus can attract more capital, allowing its government to raise taxation. As this market potential measure inherently accounts for trade integration effects (see section 3.3), no interaction with trade integration is required here.

\section{--- Table 5 about here ---}

The results reported in Table 5 - Columns (1) and (2) - confirm that the difference in market potential has a significant positive impact on the tax gap. This complements the results provided in Davies and Voget (2008) and Exbrayat (2011), which show that a countries' market potential has a positive impact on absolute levels of corporate taxation. To take the analysis one step further, Columns (3) and (4) present results when the market potential differential is decomposed into the difference in domestic and foreign market potential. This allows evaluating whether the difference in domestic market potential rather than foreign market potential matters most for governments. ${ }^{31}$ The results illustrate that both elements have a significant positive impact on the tax difference. Clearly, however, given the scale of both variables, the difference

\footnotetext{
${ }^{29}$ http://www.cepii.fr/anglaisgraph/bdd/marketpotentials.htm

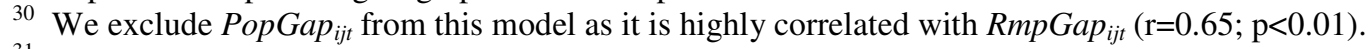

31 We approximate domestic market potential by the difference between (predicted) total market potential and (predicted) foreign market potential.
} 
in domestic market potential exerts a stronger impact. This is not surprising, as a firm's mark-up is higher for domestic sales than for foreign ones because of trade costs.

\subsubsection{Alternative constellation of control variables}

Finally, one could argue that including variables for the EMU leads to overspecification of the model, in that such variables will, by definition, be highly correlated with a shift in trade integration between the countries involved. Still, as shown in Table 6, excluding these variables does not affect our main findings.

\section{--- Table 6 about here ---}

\section{Concluding discussion}

This paper contributes to the literature on international corporate income tax competition by analysing the determinants of international tax disparities - thereby focusing on the potential role of trade integration. We build on recent insights from the tax competition literature based on New Economic Geography (NEG) frameworks to analyse the relation between asymmetric market size, trade integration and business income taxation. This literature illustrates that the difference in capital taxation between imperfectly integrated countries is increasing with their population difference, but, crucially, that this relationship is weakeend as trade costs fall. We provide the, to the best of our knowledge, first empirical test of these two predictions: $a$ ) tax differentials are a function of the coexistence of imperfect trade integration and asymmetric market sizes and $b$ ) increased trade integration reduces the ability of large countries to set higher taxes.

Our results - based on a panel dataset of 26 OECD countries over the period 1982-2004provide considerable evidence in favour of both propositions. That is, the difference in population between two countries increases the tax gap between them, ceteris paribus, and this relationship is weakened by trade liberalization. These findings are robust to different measures of corporate taxation and the inclusion of third-country and income effects. They provide one potential explanation for the considerably decline in tax disparities between OECD countries since the early 1980s (see Figure 1). Moreover, from a policy perspective, our evidence supports Ottaviano and van Ypersele's $(2005,45)$ contention that "the policy attitude towards tax 
competition [and tax coordination or harmonization] should depend on the degree of trade integration" - and substantiates the US Treasury's fear that globalization is eroding the US' ability to sustain higher tax rates compared to other countries (see introduction).

While our analysis provides a first attempt at explaining international tax disparities from a New Economic Geography perspective, various questions remain. One concerns the so-called 'home market effect': i.e., the fact that the country with a larger demand for the increasing returns industry attracts an even larger share of production. While earlier work gives somewhat mixed evidence on the existence of a home market effect in general (e.g., Davis and Weinstein, 2003; Crozet and Trionfetti, 2008; Behrens et al., 2009), another way to empirically address NEG models' predictions would be to separate between low-tax and high-tax countries in such studies. Technically, the prediction is that high-tax countries remain net importers of capital, as their attractiveness should overcompensate their higher tax-setting in equilibrium (see section 2.3.1). Another question is to what extent higher taxes set by some countries truly results from their attractiveness with respect to mobile firms or from the fact that they host an industrial cluster (which induces firms' immobility and allows governments to tax them more severely). In the latter case, the higher corporate tax rate would not result from asymmetric tax competition with an interior location equilibrium, but from rent-seeking behaviour towards immobile firms. One possibility to address this in future work might be to move the analysis from the country to the sectoral level, thereby exploiting the variation in the extent of industrial clustering across sectors (cf. Brülhart et al., 2009). Finally, it would be interesting to extend the theoretical model by allowing not only for different market sizes but also different production costs to test whether or not trade integration reduces the comparative advantage of the low-cost country. 


\section{References}

Anderson, J.E. and E. van Wincoop (2003). Gravity with Gravitas: A solution to the border puzzle. American Economic Review 93(1), 170-192.

Baier, S.L. and J.H. Bergstrand (2007). Do Free Trade Agreements Actually Increase Members' International Trade? Journal of International Economics 71(1), 72-95.

Baldwin R.E. and Krugman P. (2004). Agglomeration, integration and tax harmonisation. European Economic Review 48, 1-23.

Behrens, K., A.R. Lamorgese, G.I.P. Ottaviano and T. Tabuchi (2009). Beyond the home market effect: Market size and specialization in a multi-country world. Journal of International Economics 79(5), 259-265.

Bénassy-Quéré A., L. Fontagné and A. Lahrèche-Révil (2005). How does FDI react to corporate taxation? International Tax and Public Finance 12(5), 583-603.

Besley T., R. Griffith and A. Klemm (2001). Fiscal reaction functions, LSE, mimeo.

Brülhart, M., M. Jametti and K. Schmidheiny (2009), Do agglomeration economies reduce the sensitivity of firm location to tax differentials?, University of Lausanne, mimeo.

Bucovetsky S. (1991). Asymmetric tax competition. Journal of Urban Economics 30(2), 167181.

Charlton, A. (2003). Incentive Bidding for Mobile Investment: Economic Consequences and Potential Responses. OECD Development Centre Working Paper, nr. 203.

Crabbé K. and H. Vandenbussche (2008). Are your firm's taxes set in Warsaw? Spatial tax competition in Europe, LICOS Discussion Paper, nr. 21608.

Crozet, M. and F. Trionfetti (2008). Trade costs and the home market effect. Journal of International Economics 76, 309-321.

Davies R.B. and J. Voget (2008). Tax competition in an expanding European Union. Working Paper 08/30, Oxford University Centre for Business Taxation.

Davis, D.R. and D.E. Weinstein (2003). Market access, economic geography and comparative advantage: An empirical test. Journal of International Economics 59(1), 1-23.

Devereux M.P., Griffith R. and A. Klemm (2002). Corporate income tax: reforms and tax competition. Economic Policy 451-495.

Devereux M.P., Lockwood B. and M. Redoano (2008). Do countries compete over corporate tax rates? Journal of Public Economics 92, 1210-1235.

Dixit A.K. and J.E. Stiglitz (1977). Monopolistic competition and optimum product diversity. American Economic Review 67(3), 297-308.

Eaton, J. and S. Kortum (2002). Technology, geography and trade. Econometrica 70(5), 17411779.

Exbrayat N. (2011). Does trade liberalization trigger tax competition? Theory and evidence from OECD countries. University of Clermond-Ferrand, mimeo.

Exbrayat N., Gaigné C. and S. Riou (2010). How labor market rigidities shape business taxation in a global economy? GATE Working Paper No. 1028.

Feenstra, R. (2003). Advanced International Trade. Princeton University Press, Princeton.

Gaigné C. and S. Riou (2007). Globalization, asymmetric tax competition and fiscal equalization. Journal of Public Economic Theory 9(5), 901-925. 
Gilbert G., A. Lahrèche-Révil, T. Madiès and T. Mayer (2005). Conséquences Internationales et Locales sur L'imposition Des Entreprises. In Croissance équitable et concurrence fiscale, French Council of Economic Analysis, pp. 187-225.

Haufler A. and F. Mittermaier (2011). Unionisation triggers tax incentives to attract foreign direct investment. Economic Journal, forthcoming.

Haufler A. and I. Wooton (2010). Competition for firms in an oligopolistic industry: The impact of economic integration. Journal of International Economics 80 (2), 239-248.

Head K. and T. Mayer (2006). Regional wage and employment responses to market potential in the EU. Regional Science and Urban Economics, 36(5), 573-594.

Head K. and T. Mayer (2011). Gravity, market potential and economics development. Journal of Economic Geography, 11(2), 281-294.

Kammas, P. (2011). Strategic fiscal interaction among OECD countries. Public Choice, 147(34), 459-480.

Kind H., K. Midelfart Knarvik and G. Schjelderup (2000). Competing for capital in a lumpy world. Journal of Public Economics 78, 253-274.

Loretz S. (2008). Corporate taxation in the OECD in a wider context. Oxford Review of Economic Policy 24(4), 639-660.

Ludema R. and I. Wooton (2000). Economic geography and the fiscal effects of regional integration. Journal of International Economics 52, 331-357.

Marceau, N., S. Mongrain and J.D. Wilson (2010). Why Do Most Countries Set High Tax Rates on Capital?, Journal of International Economics 80(2), 249-259.

Melitz, M.J. and G. Ottaviano (2008). Market Size, Trade and Productivity, Review of Economic Studies, 75(1), 295-316.

Nickell, S. (1981). Biases in Dynamic Models with Fixed Effects, Econometrica 49(6), 14171426.

Ottaviano G. and T. Van Ypersele (2005). Market access and tax competition. Journal of International Economics 67, 25-46.

Pagan A. (1984). Econometric issues in the analysis of regressions with generated regressors. International Economic Review 25, 221-247.

Pieretti, P. and S. Zanaj (2011). On tax competition, public goods provision and jurisdictions' size, Journal of International Economics, 84(1), 124-130.

Redding, S. and A. Venables (2004). Economic Geography and International Inequality, Journal of International Economics 62(1), 53-82.

Rose, J., and E. Van Wincoop (2001). National money as a barrier to international trade: The real case for currency union. American Economic Review 91(2), 386-390.

Wilson J.D. (1991). Tax competition with interregional differences in factor endowments. Regional Science and Urban Economics 21(3), 423-452.

Wilson, J.D. (2005). Tax Competition with and without Preferential Treatment of a HighlyMobile Tax Base. In J. Alm, J. Martinez-Vasquez and M. Rider (Eds.), The Challenge of Tax Reform in a Global Economy, Springer, pp. 193-206.

Wooldridge, J.M. (2003). Cluster-sample methods in applied econometrics. American Economic Review 93(2), 133-138. 
Table 1: Estimation results for the baseline regression (1982-2004)

\begin{tabular}{|c|c|c|}
\hline Variable & $\begin{array}{c}\text { (1) } \\
\text { EATR }\end{array}$ & $\begin{array}{c}(2) \\
\text { EATR }\end{array}$ \\
\hline Intercept & $\begin{array}{c}0.496 * \\
(1.73)\end{array}$ & $\begin{array}{l}0.265 \\
(0.91)\end{array}$ \\
\hline$\varphi$ & $\begin{array}{l}-0.035 \\
(-0.21)\end{array}$ & $\begin{array}{c}0.886 * * * \\
(3.99)\end{array}$ \\
\hline PopGap & $\begin{array}{c}0.257 * * * \\
(17.46)\end{array}$ & - \\
\hline PopGap $* \varphi$ & $\begin{array}{c}-0.451 * * \\
(-2.24)\end{array}$ & - \\
\hline Pop-origin & - & $\begin{array}{c}10.80 * * * \\
(6.34)\end{array}$ \\
\hline Pop-origin $* \varphi$ & - & $\begin{array}{c}-21.50 * * * \\
(-4.83)\end{array}$ \\
\hline Pop-destination & - & $\begin{array}{c}-0.217 * * * \\
(-17.24)\end{array}$ \\
\hline Pop-destination $* \varphi$ & - & $\begin{array}{c}-0.188 * \\
(-1.79)\end{array}$ \\
\hline RealGDPGap & $\begin{array}{c}0.326 * * * \\
(3.81)\end{array}$ & $\begin{array}{c}0.283 * * * \\
(3.25)\end{array}$ \\
\hline PconsGap & $\begin{array}{l}-0.001 \\
(-0.61)\end{array}$ & $\begin{array}{l}-0.001 \\
(-0.77)\end{array}$ \\
\hline UnempGap & $\begin{array}{c}-0.006 * * * \\
(-11.27)\end{array}$ & $\begin{array}{c}-0.007 * * * \\
(-11.74)\end{array}$ \\
\hline OldGap & $\begin{array}{l}0.001 \\
(0.43)\end{array}$ & $\begin{array}{r}-0.001 \\
(0.68)\end{array}$ \\
\hline YouGap & $\begin{array}{c}-0.011 * * * \\
(-10.16)\end{array}$ & $\begin{array}{c}-0.011 * * * \\
(-10.42)\end{array}$ \\
\hline UrbGap & $\begin{array}{c}-0.004 * * * \\
(-5.15)\end{array}$ & $\begin{array}{c}-0.004 * * * \\
(-4.75)\end{array}$ \\
\hline LeftGap & $\begin{array}{l}-0.001 \\
(-0.81)\end{array}$ & $\begin{array}{l}-0.001 \\
(-0.78)\end{array}$ \\
\hline OpenGap & $\begin{array}{c}-0.001 * * * \\
(-5.19)\end{array}$ & $\begin{array}{c}-0.001 * * * \\
(-5.35)\end{array}$ \\
\hline EMUsingle & $\begin{array}{l}0.007 \\
(1.09)\end{array}$ & $\begin{array}{l}0.010 \\
(1.55)\end{array}$ \\
\hline EMUboth & $\begin{array}{l}0.003 \\
(0.51) \\
\end{array}$ & $\begin{array}{l}0.009 \\
(1.35) \\
\end{array}$ \\
\hline $\begin{array}{l}\text { Country dummies }(\mathrm{O} \& \mathrm{D}) \\
\text { Year dummies } \\
\text { Trend }\end{array}$ & $\begin{array}{l}\text { Yes } \\
\text { Yes } \\
\text { Yes }\end{array}$ & $\begin{array}{l}\text { Yes } \\
\text { Yes } \\
\text { Yes }\end{array}$ \\
\hline $\begin{array}{l}\mathrm{N} \\
\mathrm{R}^{2} \text { (overall) }\end{array}$ & $\begin{array}{l}4730 \\
0.812 \\
\end{array}$ & $\begin{array}{l}4730 \\
0.816 \\
\end{array}$ \\
\hline
\end{tabular}

Note: Dependent variable: EATRGap; t-statistics based on heteroscedasticityconsistent standard errors and clustered by origin-country-year in parenthesis: $* * *$ significant at $1 \%, * *$ at $5 \%$ and $*$ at $10 \%$. 
Table 2: Results using alternative tax measures and introducing lagged dependent variable (1982-2004)

\begin{tabular}{|c|c|c|c|c|c|c|c|c|}
\hline Variable & $\begin{array}{c}\text { (3) } \\
\text { EATR }\end{array}$ & $\begin{array}{c}\text { (4) } \\
\text { EATR }\end{array}$ & $\begin{array}{c}\text { (5) } \\
\text { EMTR }\end{array}$ & $\begin{array}{c}\text { (6) } \\
\text { EMTR }\end{array}$ & $\begin{array}{c}(7) \\
\text { EMTR }\end{array}$ & $\begin{array}{c}(8) \\
\text { Stattax }\end{array}$ & $\begin{array}{c}\text { (9) } \\
\text { Stattax }\end{array}$ & $\begin{array}{c}(10) \\
\text { Stattax }\end{array}$ \\
\hline Intercept & $\begin{array}{l}0.011 \\
(0.13)\end{array}$ & $\begin{array}{l}-0.034 \\
(-0.37)\end{array}$ & $\begin{array}{c}0.555^{*} \\
(1.65)\end{array}$ & $\begin{array}{l}0.049 \\
(0.48)\end{array}$ & $\begin{array}{l}-0.010 \\
(-0.10)\end{array}$ & $\begin{array}{l}0.487 \\
(1.62)\end{array}$ & $\begin{array}{l}0.037 \\
(0.37)\end{array}$ & $\begin{array}{l}-0.026 \\
(-0.25)\end{array}$ \\
\hline Lagged dependent variable & $\begin{array}{c}0.679 * * * \\
(18.74)\end{array}$ & $\begin{array}{c}0.674 * * * \\
(18.45)\end{array}$ & - & $\begin{array}{c}0.648 * * * \\
(16.81)\end{array}$ & $\begin{array}{c}0.769 * * * \\
(16.49)\end{array}$ & - & $\begin{array}{c}0.685 * * * \\
(19.49)\end{array}$ & $\begin{array}{c}0.679 * * * \\
(19.15)\end{array}$ \\
\hline$\varphi$ & $\begin{array}{l}0.119 \\
(1.50)\end{array}$ & $\begin{array}{c}0.457 * * * \\
(3.26)\end{array}$ & $\begin{array}{l}0.007 \\
(0.03)\end{array}$ & $\begin{array}{l}0.142 \\
(1.50)\end{array}$ & $\begin{array}{c}0.506 * * * \\
(3.25)\end{array}$ & $\begin{array}{l}-0.149 \\
(-0.86)\end{array}$ & $\begin{array}{l}0.042 \\
(0.48)\end{array}$ & $\begin{array}{c}0.529 * * * \\
(3.37)\end{array}$ \\
\hline PopGap & $\begin{array}{c}0.073 * * * \\
(4.80)\end{array}$ & - & $\begin{array}{c}0.272 * * * \\
(15.14)\end{array}$ & $\begin{array}{c}0.089 * * * \\
(5.27)\end{array}$ & - & $\begin{array}{c}0.284 * * * \\
(16.26)\end{array}$ & $\begin{array}{c}0.092 * * * \\
(5.14)\end{array}$ & - \\
\hline PopGap $* \varphi$ & $\begin{array}{c}-0.244^{*} \\
(-1.76)\end{array}$ & - & $\begin{array}{c}-0.466^{* * *} \\
(-2.00)\end{array}$ & $\begin{array}{c}-0.286^{*} \\
(-1.79)\end{array}$ & - & $\begin{array}{c}-0.684 * * \\
(-2.49)\end{array}$ & $\begin{array}{c}-0.369^{* *} \\
(-2.19)\end{array}$ & - \\
\hline Pop-origin & - & $\begin{array}{c}0.234 * * * \\
(2.84)\end{array}$ & - & - & $\begin{array}{c}0.245 * * * \\
(2.85)\end{array}$ & - & - & $\begin{array}{c}0.314 * * * \\
(2.94)\end{array}$ \\
\hline Pop-origin $* \varphi$ & - & $\begin{array}{c}-0.915^{* *} \\
(-2.32)\end{array}$ & - & - & $\begin{array}{c}-0.953^{* *} \\
(-2.22)\end{array}$ & - & - & $\begin{array}{c}-13.50^{* * * *} \\
(-3.27)\end{array}$ \\
\hline Pop-destination & - & $\begin{array}{c}-0.065^{* * * *} \\
(-4.38)\end{array}$ & - & - & $\begin{array}{c}-0.055 * * * \\
(-4.95)\end{array}$ & - & - & $\begin{array}{c}-0.083 * * * \\
(-4.61)\end{array}$ \\
\hline Pop-destination $* \varphi$ & - & $\begin{array}{l}0.005 \\
(0.08) \\
\end{array}$ & - & - & $\begin{array}{l}0.006 \\
(0.25) \\
\end{array}$ & - & - & $\begin{array}{l}0.022 \\
(0.27) \\
\end{array}$ \\
\hline $\mathrm{N}$ & 4103 & 4103 & 4730 & 4103 & 4103 & 4993 & 4439 & 4103 \\
\hline $\mathrm{R}^{2}$ (overall) & 0.935 & 0.935 & 0.760 & 0.923 & 0.923 & 0.819 & 0.931 & 0.931 \\
\hline Anderson Canonical & $3385.5 * * *$ & $3330.2 * * *$ & & $3496.1 * * *$ & $3445.7 * * *$ & & $3787.1 * * *$ & $3741.5^{* * *}$ \\
\hline Hansen & 0.358 & 0.357 & & 0.007 & 0.007 & & $3.353^{*}$ & $3.375^{*}$ \\
\hline
\end{tabular}


Table 3: Estimation results for the extended regression (1982-2004)

\begin{tabular}{l|cc}
\hline Variable & EATR (11) & EATR (12) \\
\hline Intercept & 0.462 & 0.007 \\
Lagged dependent variable & $(1.62)$ & $(0.08)$ \\
& - & $0.680^{* * *}$ \\
$\varphi$ & -0.004 & $(18.76)$ \\
& $(-0.01)$ & $0.484^{* *}$ \\
$\varphi^{2}$ & 2.026 & $-6.101^{* * *}$ \\
& $(0.45)$ & $(-2.60)$ \\
PopGap & $0.239^{* * *}$ & $0.070^{* * *}$ \\
& $(13.96)$ & $(4.34)$ \\
PopGap $* \varphi$ & $11.000^{* *}$ & -0.314 \\
& $(2.00)$ & $(-0.93)$ \\
PopGap $* \varphi^{2}$ & $-315.600^{* * *}$ & 26.000 \\
& $(-3.47)$ & $(0.53)$ \\
\hline $\mathrm{N}$ & 4730 & 4103 \\
$\mathrm{R}^{2}$ (overall) & 0.812 & 0.935 \\
Anderson Canonical & & $3372.0^{* * *}$ \\
Hansen & & 0.396 \\
\hline
\end{tabular}

Note: Dependent variable: EATRGap; t-statistics based on heteroscedasticity-consistent standard errors and clustered by origin-country-year in parenthesis: *** significant at $1 \%, * *$ at $5 \%$ and $*$ at $10 \%$. Anderson Canonical correlation statistic tests for weak identifying restrictions, while Hansen is the test for over-identifying restrictions. Control variables as in Table 1 included in every regression. 
Table 4: Controlling for third-country effects (1982-2004)

\begin{tabular}{|c|c|c|c|c|c|c|}
\hline Variable & $\begin{array}{c}(13) \\
\text { EATR }\end{array}$ & $\begin{array}{c}(14) \\
\text { EATR }\end{array}$ & $\begin{array}{c}(15) \\
\text { EMTR }\end{array}$ & $\begin{array}{c}\text { (16) } \\
\text { EMTR }\end{array}$ & $\begin{array}{c}(17) \\
\text { Stattax }\end{array}$ & $\begin{array}{c}(18) \\
\text { Stattax }\end{array}$ \\
\hline Intercept & $\begin{array}{l}12.112 * * * \\
(6.91)\end{array}$ & $\begin{array}{c}3.194 * * * \\
(3.24)\end{array}$ & $\begin{array}{c}14.906 * * * \\
(6.93)\end{array}$ & $\begin{array}{l}4.114 * * * \\
\quad(3.43)\end{array}$ & $\begin{array}{c}10.018 * * * \\
(5.62)\end{array}$ & $\begin{array}{l}3.259 * * * \\
(2.63)\end{array}$ \\
\hline $\begin{array}{l}\text { Lagged dependent } \\
\text { variable }\end{array}$ & - & $\begin{array}{c}0.667 * * * \\
(18.03)\end{array}$ & - & $\begin{array}{l}0.634 * * * \\
(16.09)\end{array}$ & - & $\begin{array}{c}0.679 * * * \\
(18.94)\end{array}$ \\
\hline$\varphi$ & $\begin{array}{l}-0.099 \\
(-0.68)\end{array}$ & $\begin{array}{l}0.067 \\
(0.84)\end{array}$ & $\begin{array}{l}-0.075 \\
(-0.42)\end{array}$ & $\begin{array}{l}0.080 \\
(0.86)\end{array}$ & $\begin{array}{l}-0.199 \\
(-1.22)\end{array}$ & $\begin{array}{l}0.001 \\
(0.01)\end{array}$ \\
\hline PopGap & $\begin{array}{c}0.261 * * * \\
(19.24)\end{array}$ & $\begin{array}{c}0.082 * * * \\
(5.02)\end{array}$ & $\begin{array}{l}0.279 * * * \\
(17.29)\end{array}$ & $\begin{array}{c}0.099 * * * \\
(5.60)\end{array}$ & $\begin{array}{c}0.285 * * * \\
(16.62)\end{array}$ & $\begin{array}{l}0.101 * * * \\
\quad(5.02)\end{array}$ \\
\hline PopGap $* \varphi$ & $\begin{array}{c}-0.383 * * \\
(-1.96)\end{array}$ & $\begin{array}{c}-0.218^{*} \\
(-1.65)\end{array}$ & $\begin{array}{c}-0.380 * \\
(-1.71)\end{array}$ & $\begin{array}{c}-0.253^{*} \\
(-1.65)\end{array}$ & $\begin{array}{c}-0.634 * * \\
(-2.29)\end{array}$ & $\begin{array}{c}-0.346^{* *} \\
(-2.12)\end{array}$ \\
\hline Openness & $\begin{array}{c}-0.012 * * * \\
(-5.66)\end{array}$ & $\begin{array}{c}-0.005 * * * \\
(-2.87)\end{array}$ & $\begin{array}{c}-0.015 * * * \\
(-6.03)\end{array}$ & $\begin{array}{c}-0.006 * * * \\
(-3.07)\end{array}$ & $\begin{array}{c}-0.009 * * * \\
(-3.90)\end{array}$ & $\begin{array}{c}-0.004 * * \\
(-2.09)\end{array}$ \\
\hline RelPop & $\begin{array}{c}12.2 * * * \\
(6.67)\end{array}$ & $\begin{array}{c}3.30 * * * \\
(3.24)\end{array}$ & $\begin{array}{c}15.1 * * * \\
(6.70)\end{array}$ & $\begin{array}{l}0.422 * * * \\
(3.40)\end{array}$ & $\begin{array}{c}10.100 * * * \\
(5.39)\end{array}$ & $\begin{array}{l}0.336 * * * \\
(2.61)\end{array}$ \\
\hline RelPop * Openness & $\begin{array}{c}-0.010 * * * \\
(-5.93)\end{array}$ & $\begin{array}{c}-0.004 * * * \\
(-3.02)\end{array}$ & $\begin{array}{c}-0.001 * * * \\
(-6.27)\end{array}$ & $\begin{array}{c}-0.001 * * * \\
(-3.21)\end{array}$ & $\begin{array}{c}-0.0001 * * * \\
(-4.05)\end{array}$ & $\begin{array}{c}-0.0004 * * \\
(-2.21)\end{array}$ \\
\hline $\mathrm{N}$ & 4730 & 4103 & 4730 & 4103 & 4993 & 4439 \\
\hline $\mathrm{R}^{2}$ (overall) & 0.819 & 0.936 & 0.770 & 0.924 & 0.822 & 0.931 \\
\hline Anderson & & $3304.8 * * *$ & & $3414.0 * * *$ & & $3745.9 * * *$ \\
\hline Hansen & & 0.463 & & 0.028 & & $3.335^{*}$ \\
\hline
\end{tabular}

Note: t-statistics based on heteroscedasticity-consistent standard errors and clustered by origin-country-year in parenthesis: $* * *$ significant at $1 \%, * *$ at $5 \%$ and $*$ at $10 \%$. Anderson Canonical correlation statistic tests for weak identifying restrictions, while Hansen is the test for over-identifying restrictions. Control variables as in Table 1 included in every regression. 
Table 5: Robustness checks: Introducing market potential (1982-2003)

\begin{tabular}{|c|c|c|c|c|}
\hline Variable & $\begin{array}{c}\text { (19) } \\
\text { EATR }\end{array}$ & $\begin{array}{c}(20) \\
\text { EATR }\end{array}$ & $\begin{array}{c}\text { (21) } \\
\text { EATR }\end{array}$ & $\begin{array}{c}(22) \\
\text { EATR }\end{array}$ \\
\hline Intercept & $\begin{array}{l}0.064 \\
(0.23)\end{array}$ & $\begin{array}{l}0.003 \\
(0.03)\end{array}$ & $\begin{array}{l}0.197 \\
(0.76)\end{array}$ & $\begin{array}{l}0.039 \\
(0.36)\end{array}$ \\
\hline $\begin{array}{l}\text { Lagged dependent } \\
\text { variable }\end{array}$ & - & $\begin{array}{c}0.649 * * * \\
(17.48)\end{array}$ & - & $\begin{array}{c}0.631 * * * \\
(15.66)\end{array}$ \\
\hline$\varphi$ & $\begin{array}{l}-0.070 \\
(-0.35)\end{array}$ & $\begin{array}{l}0.129 \\
(1.24)\end{array}$ & $\begin{array}{l}-0.056 \\
(-0.30)\end{array}$ & $\begin{array}{l}0.129 \\
(1.28)\end{array}$ \\
\hline RmpGap & $\begin{array}{l}1.66^{* * * *} \\
(13.21)\end{array}$ & $\begin{array}{l}0.651 * * * \\
(6.19)\end{array}$ & - & - \\
\hline DRmpGap & - & - & $\begin{array}{l}1.520 * * * \\
(7.86)\end{array}$ & $\begin{array}{c}0.653 * * \\
(2.34)\end{array}$ \\
\hline FRmpGap & - & - & $\begin{array}{c}0.0004 * * * \\
(11.47)\end{array}$ & $\begin{array}{c}0.0001 * * * \\
(6.15)\end{array}$ \\
\hline $\mathrm{N}$ & 4477 & 3850 & 4477 & 3850 \\
\hline $\mathrm{R}^{2}$ (overall) & 0.823 & 0.937 & 0.830 & 0.937 \\
\hline Anderson & & $3020.2 * * *$ & & $2826.1 * * *$ \\
\hline Hansen & & 0.265 & & 0.148 \\
\hline
\end{tabular}

Note: t-statistics based on heteroscedasticity-consistent standard errors and clustered by origin-country-year in parenthesis: $* * *$ significant at $1 \%, * *$ at $5 \%$ and $*$ at $10 \%$. Anderson Canonical correlation statistic tests for weak identifying restrictions, while Hansen is the test for over-identifying restrictions. Control variables as in Table 1 included in every regression. 
Table 6: Excluding EMU-variables (1982-2004)

\begin{tabular}{l|cc} 
& $\mathbf{( 2 3 )}$ & $\mathbf{( 2 4 )}$ \\
Variable & EATR & EATR \\
\hline Intercept & $0.502^{*}$ & 0.019 \\
& $(1.73)$ & $(0.20)$ \\
Lagged dependent & - & $0.678^{* * *}$ \\
variable & & $(18.34)$ \\
$\varphi$ & -0.030 & 0.136 \\
& $(-0.17)$ & $(1.63)$ \\
PopGap & $0.258^{* * *}$ & $0.076^{* * *}$ \\
& $(17.88)$ & $(4.79)$ \\
PopGap $* \varphi$ & $-0.461^{* *}$ & $-0.254^{*}$ \\
& $(-2.21)$ & $(-1.76)$ \\
\hline $\mathrm{N}$ & 4730 & 4103 \\
$\mathrm{R}^{2}$ (overall) & 0.811 & 0.935 \\
Anderson & & $3383.4^{* * *}$ \\
Hansen & & 0.264 \\
\hline
\end{tabular}

Note: t-statistics based on heteroscedasticity-consistent standard errors and clustered by origin-countryyear in parenthesis: $* * *$ significant at $1 \%, * *$ at $5 \%$ and $*$ at $10 \%$. Anderson Canonical correlation statistic tests for weak identifying restrictions, while Hansen is the test for over-identifying restrictions. Control variables as in Table 1 included in every regression, except EMUsingle and EMUboth. 
Figure 1: Corporate tax rate levels and convergence in OECD countries

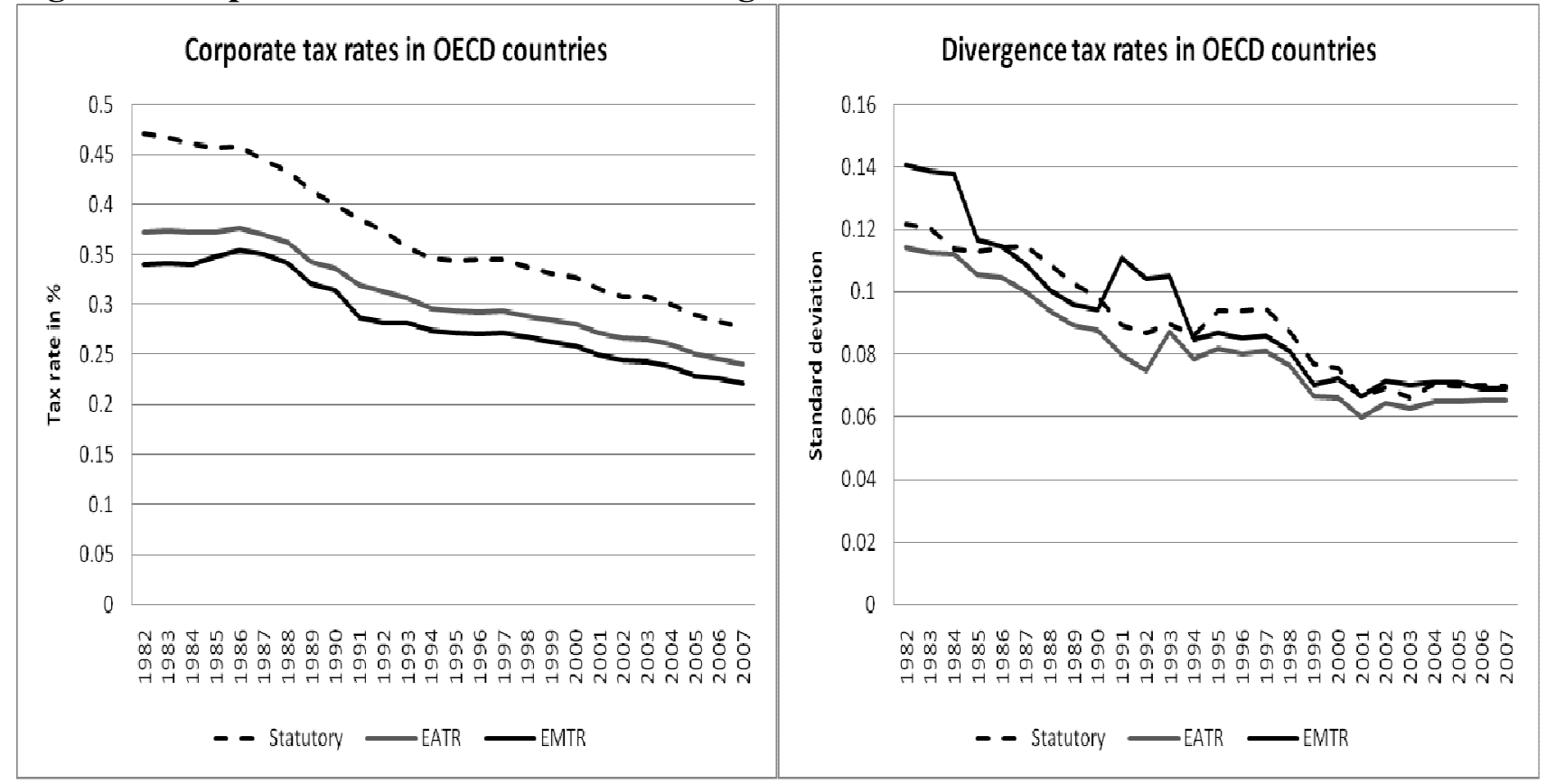


Figure 2: Graphical representation of interaction effects (baseline regression)

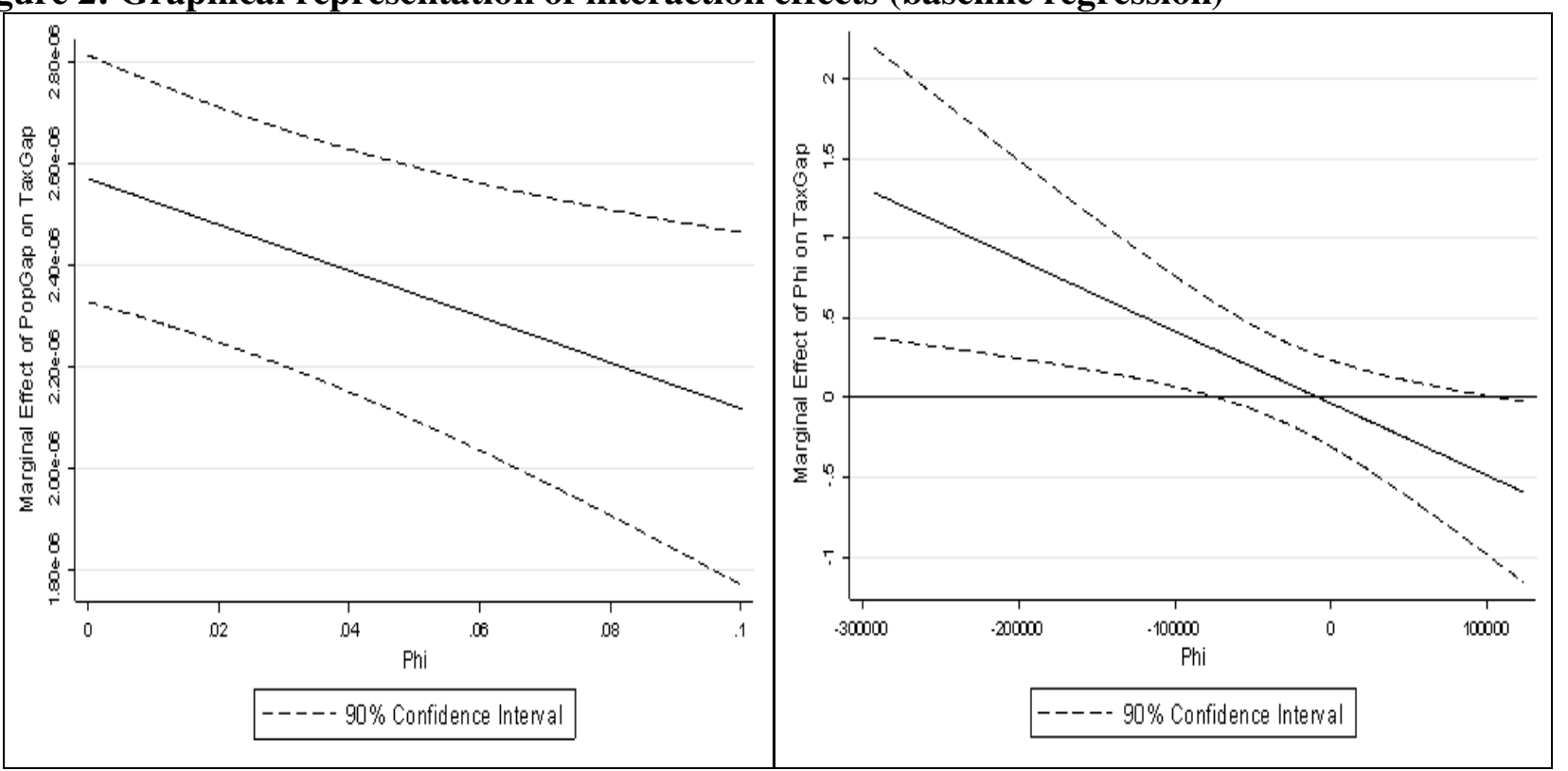


Figure 3: Trade costs and the tax gap

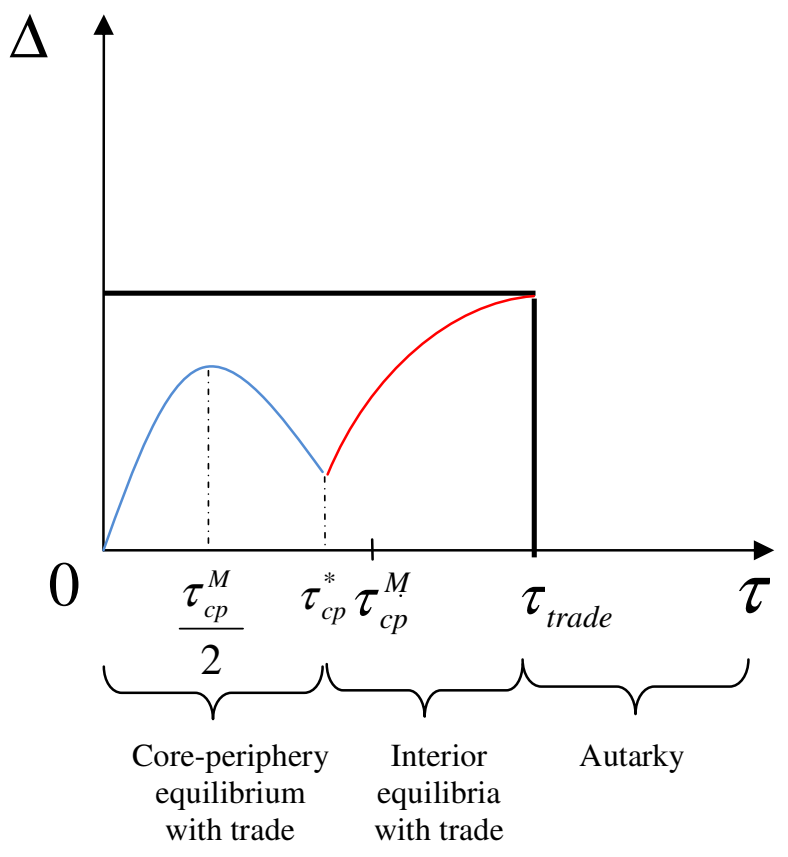




\section{Appendix A: The three-country model}

Consider an economy consisting of three imperfectly integrated countries $(i=1,2,3)$, with a share $\sigma_{i} \in(0,1)$ of the total population $(L)$ living in country $i$ and the same level of trade integration the across country-pairs. ${ }^{32}$

The consumption behaviour is similar to that of the two country model (see Section 2.1). Firms' operating profits now depend on sales made in the domestic and the two foreign countries. In the following, we present output levels for a firm located in country 1 (symmetric expressions hold for firms located in the other countries), whose level of operating profit is:

$$
\Pi_{1}=\left(p_{1}-w\right) x_{11}+\left(p_{2}-w-\tau\right) x_{12}+\left(p_{3}-w-\tau\right) x_{13}
$$

Maximizing the above expression taking into account demand yields the following output levels:

$$
x_{11}=\frac{\sigma_{1} L}{\beta} \frac{a-w+\tau K\left(1-\lambda_{1}\right)}{K+1}, \quad x_{12}=\frac{\sigma_{2} L}{\beta} \frac{a-w-\tau\left(K \lambda_{2}+1\right)}{K+1}, \quad x_{13}=\frac{\sigma_{3} L}{\beta} \frac{a-w-\tau\left(K \lambda_{3}+1\right)}{K+1}
$$

where $\lambda_{i} \in(0,1)$ stands for the share of the capital stock invested in country $i$. Observe that these expressions are similar to those of the two-country model: i.e., supply for a given market is decreasing with the share of firms located in this country, and this competition effect is strengthened by the level of trade costs.

The resulting price equilibrium in country $i$ is given by:

$$
p_{i}=\frac{a+\tau\left(1-\lambda_{i}\right) K+w K}{K+1}
$$

which has, again, the same properties as in the two-country model. We assume, as before, that the level of trade cost is not prohibitive so that it is always profitable for a firm to export $\left(\tau<\tau_{\text {trade }}=(a-w) /(K+1)\right)$.

In the long run, the spatial distribution of firms is found by solving the arbitrage condition according to which no unit of capital can induce a higher net return by being invested in another country; that is, when $\Pi_{1}^{*}-t_{1}=\Pi_{2}^{*}-t_{2}=\Pi_{3}^{*}-t_{3}=r$. In the free-market equilibrium characterized by the absence of fiscal policy, the resulting share of firms located in country $i$ is:

\footnotetext{
${ }^{32}$ Clearly, in reality, levels of trade integration are likely to vary across country-pairs. We rely on this simplification here as an extension of the 3-country model allowing for different levels of trade costs across country-pairs becomes (very close to) intractable. This assumption is relaxed in the empirical analysis in section 3.3.4.
} 


$$
\lambda_{i}^{M}=\frac{1}{K \tau} \frac{K \tau \sigma_{i}\left(1-\sigma_{i}\right)+(2 a-2 w-\tau)\left(\frac{1}{2} \sum_{i=1}^{3} \sigma_{i}\left(1-\sigma_{i}\right)-3 \prod_{j \neq i} \sigma_{j}\right)}{\sum_{i=1}^{3} \sigma_{i}\left(1-\sigma_{i}\right)}
$$

Note that the main incentives to locate in the largest market are still at work in this three-country model. More precisely, the share of capital invested in a country is increasing with the share of total population in this country, and this effect strengthens as trade costs fall.

Now, assuming that governments implement a redistributive fiscal policy, the share of capital invested in country 1 becomes:

$$
\lambda_{1}=\lambda_{1}^{M}-\frac{\beta(K+1)}{K L \tau^{2}} \frac{\sigma_{2}\left(t_{1}-t_{3}\right)+\sigma_{3}\left(t_{1}-t_{2}\right)}{\sum_{i=1}^{3} \sigma_{i}\left(1-\sigma_{i}\right)}
$$

and symmetric expressions hold for the share of capital invested in countries 2 and 3. Thus, intuitively, the share of capital invested in a country decreases with the tax differential with respect to each of the other countries.

Let us now describe the tax competition outcome. We focus on the most realistic case of interior location equilibria. ${ }^{33}$ In order to assess the importance of third-country effects on tax differentials, we describe the tax gap between countries 1 and 2 and consider country 3 as the rest of the world. Let us denote by $\Omega=\left(\sigma_{1}-\sigma_{2}\right) L$ the population differential between countries 1 and $2 .{ }^{34}$ Their bilateral tax gap $\left(\Delta_{12}^{*}=t_{1}^{*}-t_{2}^{*}\right)$ is given by:

$$
\Delta_{12}^{*}=\Omega \frac{\tau}{\beta} \frac{2(a-w) \Phi-\tau \Sigma}{2 K(2 K \Xi-\Lambda)+\Gamma}
$$

where $\Phi, \Sigma, \Xi, \Lambda$ and $\Gamma$ are bundles of parameters that depend exclusively on the distribution of capital ownership (available upon request). We check that $\Phi, \Xi$ and $\Gamma$ are positive for all $\sigma_{i} \in(0,1)$, whereas the sign of $\Sigma$ and $\Lambda$ is ambiguous.

The bilateral tax gap in the three-country model (7) closely mirrors that of the twocountry model (6a). Indeed, observe that: i) the tax gap between two countries is proportional to

\footnotetext{
33 When trade costs reach low values, all capital is invested in the most populated country and the tax competition game is equivalent to the core-periphery case described in section 2.3.1, except that there are now two peripheral countries. Proposition 1 also holds under such a configuration. Results are available upon request.

34 We verify that the reaction functions are linear, with a slope positive and lower than unity, as in the two-country model.
} 
their population differential and ii) is equal to zero if and only if countries are equal-sized. ${ }^{35} \mathrm{In}$ order to determine more precisely the properties of the tax gap (7), we need to determine the sign of the two following derivatives:

$$
\frac{d \Delta_{12}^{*}}{d \Omega}=\frac{\tau}{\beta} \frac{2(a-w) \Phi-\tau \Sigma}{2 K(2 K \Xi-\Lambda)+\Gamma} \quad \text { and } \quad \frac{d^{2} \Delta_{12}^{*}}{d \Omega d \tau}=\frac{2}{\beta} \frac{(a-w) \Phi-\tau \Sigma}{2 K(2 K \Xi-\Lambda)+\Gamma}
$$

After tedious calculations, we show that these derivatives are both positive. We summarize these results by the following proposition.

Proposition 1-bis (three-country model): Assume tax competition between three benevolent governments of differently populated countries. For interior location equilibria:

(i) The tax gap between two countries is increasing with the difference in population between these countries, for a given population in the rest of the world.

(ii) This relationship is mitigated as trade costs fall.

Proof of Proposition 1-bis $i$ ):

We first show that:

$$
2 K(2 K \Xi-\Lambda)+\Gamma>0
$$

Recall that $\Xi$ is positive. Moreover, we evaluate whether $\Gamma-2 K \Lambda$ is positive for all admissible values of $\sigma_{i}$, so that inequality (8) always holds.

Then, we show that:

$$
2(a-w) \Phi-\tau \Sigma>0
$$

Observe that this expression is a monotonic function of $\tau$, and is positive when trade costs equal zero. Moreover, since we assumed that trade costs take only non-prohibitive values $\left(\tau<\tau_{\text {trade }}\right)$, a sufficient condition for inequality (9) to hold is that $2(a-w) \Phi-\tau_{\text {trade }} \Sigma>0$. We can show that $2(a-w) \Phi-\tau_{\text {trade }} \Sigma=\tau_{\text {trade }} \mathrm{Z}$, with $\mathrm{Z}$ a bundle of parameters which is positive for all admissible values of $\sigma_{i}$. Thus, inequality (9) holds for non-prohibitive trade costs and we can conclude that $d \Delta_{12}^{*} / d \Omega>0$.

35 Observe, however, that the total capital stock had second-order effects on the tax gap in the two-country model whereas these second-order effects depend on the spatial distribution of capital ownership in the three-country model. 
Proof of Proposition 1-bis ii):

Given the inequality (8), we get $d^{2} \Delta_{12}^{*} / d \Omega d \tau>0$ provided that

$$
(a-w) \Phi-\tau \Sigma>0
$$

Similar to before, this expression is a monotonic function of $\tau$, and is positive when trade costs equal zero. Thus, a sufficient condition for inequality (10) to hold is that $(a-w) \Phi-\tau_{\text {trade }} \Sigma>0$. After manipulations, we get: $(a-w) \Phi-\tau_{\text {trade }} \Sigma=K \tau_{\text {trade }}(2 K \Psi+\Theta)$, with $\Psi$ and $\Theta$ bundle of parameters that depend exclusively on $\sigma_{i}$. For all admissible values of $\sigma_{i}, \Psi$ is positive. This implies that $K \tau_{\text {trade }}(2 K \Psi+\Theta)$ is positive for all $K>-\Theta / 2 \Psi$. Using the fact that parameters $\sigma_{i}$ lie in the interval $(0,1)$, simulations show that $-\Theta / 2 \Psi \in(-2,1 / 2)$. Finally, recall that we assume oligopolistic competition, with a perfect correspondence between the number of firms and capital units so that $K$ is higher than unity. Hence, the inequalities $K>-\Theta / 2 \Psi$ and (10) hold for all admissible values of $K, \tau$ and $\sigma_{i}$ and we can conclude that $d^{2} \Delta_{12}^{*} / d \Omega d \tau>0$. 


\section{Appendix B: Data sources and summary statistics}

$E A T R_{i t}$ : Effective Average Tax Rate (source: Devereux et al., 2002).

$E M T R_{i t}$ : Effective Marginal Tax Rate (source: Devereux et al., 2002).

$E A T R_{i t}:$ Statutory Tax Rate (source: Devereux et al., 2002).

$\varphi_{i j t}$ : Trade integration index (own calculations using Trade and Production and Gravity databases of CEPII).

$R m p_{i t}$ : Real market potential (source: CEPII)

FRmp it: Foreign real market potential

$\operatorname{DRmp}_{i t}$ : Domestic real market potential

$P C O N S_{i t}$ : public consumption in percentage of GDP per capita (source: Penn World Tables).

$U N E M P_{i t}$ : standardized unemployment rate (source: OECD Social Expenditures database).

RealGDP $i t$ : real GDP per capita (source: Penn World Tables).

$P O P_{i t}$ : population (in thousand) (source: Penn World Tables).

$O P E N_{i t}$ : trade openness (source: Penn World Tables).

$L E F T_{i t}$ : Coded 1 if executive right-wing, 0 if centre and -1 if left-wing (source: World Bank: Database of Political Institutions).

$U R B_{i t}$ : proportion of population living in urban areas (source: World Bank Development Indicators).

$O L D_{i t}$ : proportion of population over age 65 (source: World Bank Development Indicators).

$Y O U_{i t}$ : proportion of population under age 14 (source: World Bank Development Indicators).

EMUsingle $e_{i t}$ : dummy $=1$ if only one country in a country-pair $i j$ is member of EMU (or its predecessors).

$E M U b o t h_{i t}$ : dummy $=1$ if both countries in a country-pair $i j$ are member of EMU (or its predecessors).

Summary statistics for variables in differences (1982-2004)

\begin{tabular}{l|cccc}
\hline Variable & Mean & Std. Dev. & Min. & Max. \\
\hline EATRGap & -0.006 & 0.119 & -0.460 & 0.469 \\
EMTRGap & -0.007 & 0.128 & -0.511 & 0.524 \\
StattaxGap & -0.004 & 0.139 & -0.55 & 0.517 \\
RmpGap & -0.00034 & 0.00237 & -104.00 & 0.00743 \\
FRmpGap & 1.34 E-06 & $6.36 \mathrm{E}-06$ & $-32.6 \mathrm{E}-06$ & $32.5 \mathrm{E}-06$ \\
DRmpGap & -0.00034 & 0.00237 & -104.00 & 0.00743 \\
PopGap & -0.01997 & 0.08092 & -0.29251 & 0.12347 \\
OldGap & 0.095 & 2.929 & -8.450 & 7.450 \\
YouGap & -0.727 & $3-899$ & -13.66 & 12.14 \\
UrbGap & 1.934 & 15.613 & -38.8 & 44.8 \\
RealGDPGap & 0.00091 & 0.0069 & -0.0279 & 0.0282 \\
PconsGap & -1.151 & 5.931 & -26.02 & 22.93 \\
UnempGap & 0.696 & 5.764 & -20.5 & 21.2 \\
LeftGap & -0.076 & 1.284 & -2 & 2 \\
OpenGap & 0.561 & 38.963 & -142.011 & 163.823 \\
\hline
\end{tabular}

Note: RealGDPGap in million; PopGap in billion; RmpGap, FRmpGap and DrmpGap in trillion (to make coefficient estimates more readable in Tables 1 through 6).

Summary statistics for estimated trade integration variable (1982-2004)

\begin{tabular}{l|llllll}
\hline $\boldsymbol{\varphi}$ & Mean & Std. Dev. & Min & Max & \multicolumn{2}{c}{ Observations } \\
\hline Overall & 0.00233 & 0.00632 & $1.39 \mathrm{e}-07$ & 0.10009 & $\mathrm{~N}=$ & 8125 \\
Between country-pairs & & 0.00294 & 0.00018 & 0.02043 & $\mathrm{n}=$ & 325 \\
Within country-pairs & & 0.00559 & -0.01806 & 0.08199 & $\mathrm{~T}=$ & 25 \\
\hline
\end{tabular}

